\title{
Corporate Governance and the Value of Excess Cash Holdings of Large European Firms
}

\author{
Marc B.J. Schauten, Dick van Dijk and Jan-Paul van der Waal
}

\begin{tabular}{|l|l|}
\hline \multicolumn{2}{|l|}{ ERIM REPORT SERIES RESEARCH IN MANAGEMENT } \\
\hline ERIM Report Series reference number & ERS-2008-027-F\&A \\
\hline Publication & May 2008 \\
\hline Number of pages & 37 \\
\hline Persistent paper URL & http://hdl.handle.net/1765/12465 \\
\hline Email address corresponding author & djvandijk@few.eur.nl \\
\hline Address & Erasmus Research Institute of Management (ERIM) \\
& RSM Erasmus University / Erasmus School of Economics \\
& Erasmus Universiteit Rotterdam \\
& P.O.Box 1738 \\
& 3000 DR Rotterdam, The Netherlands \\
& Phone: + 31 10 408 1182 \\
& Fax: + 3110 408 9640 \\
& Email: info@erim.eur.nl \\
& Internet: www.erim.eur.nl \\
\hline
\end{tabular}

Bibliographic data and classifications of all the ERIM reports are also available on the ERIM website: www.erim.eur.nl 


\section{ERASMUS RESEARCH INSTITUTE OF MANAGEMENT}

\section{REPORT SERIES}

\section{RESEARCH IN MANAGEMENT}

\begin{tabular}{|c|c|}
\hline \multicolumn{2}{|c|}{ ABSTRACT AND KEYWORDS } \\
\hline Abstract & $\begin{array}{l}\text { We examine the relation between the quality of corporate governance and the value of excess } \\
\text { cash for large European firms (FTSEurofirst } 300 \text { Index). We use Deminor ratings for Shareholder } \\
\text { rights, Takeover defences, Disclosure and Board as proxies for the quality of corporate } \\
\text { governance. We find that the value of excess cash is positively related to the Takeover defences } \\
\text { score only. It seems that governance mechanisms-except the market for corporate control- } \\
\text { are not strong enough to prevent managers from wasting excess cash. For non-UK firms we find } \\
\text { that the value of } € 1 \text { of excess cash in a poorly governed firm is valued at only } € 0.89 \text { while the } \\
\text { value is } € 1.45 \text { for a good governed firm. We show that poorly governed firms dissipate excess } \\
\text { cash relatively quickly with a negative impact on their operating performance as a result. }\end{array}$ \\
\hline Free Keywords & corporate governance, excess cash, take-over defences \\
\hline Availability & $\begin{array}{l}\text { The ERIM Report Series is distributed through the following platforms: } \\
\text { Academic Repository at Erasmus University (DEAR), DEAR ERIM Series Portal } \\
\text { Social Science Research Network (SSRN), SSRN ERIM Series Webpage } \\
\text { Research Papers in Economics (REPEC), REPEC ERIM Series Webpage }\end{array}$ \\
\hline Classifications & $\begin{array}{l}\text { The electronic versions of the papers in the ERIM report Series contain bibliographic metadata } \\
\text { by the following classification systems: } \\
\text { Library of Congress Classification, (LCC) LCC Webpage } \\
\text { Journal of Economic Literature, (JEL), JEL Webpage } \\
\text { ACM Computing Classification System CCS Webpage } \\
\text { Inspec Classification scheme (ICS), ICS Webpage }\end{array}$ \\
\hline
\end{tabular}




\title{
Corporate governance and the value of excess cash holdings of large European firms
}

\author{
Marc B.J. Schauten* \\ Department of Finance \\ Erasmus University Rotterdam
}

\author{
Dick van Dijk \\ Econometric Institute \\ Erasmus University Rotterdam
}

\author{
Jan-Paul van der Waal \\ Erasmus University Rotterdam
}

May 14, 2008

\begin{abstract}
We examine the relation between the quality of corporate governance and the value of excess cash for large European firms (FTSEurofirst 300 Index). We use Deminor ratings for Shareholder rights, Takeover defences, Disclosure and Board as proxies for the quality of corporate governance. We find that the value of excess cash is positively related to the Takeover defences score only. It seems that governance mechanisms-except the market for corporate control-are not strong enough to prevent managers from wasting excess cash. For non-UK firms we find that the value of $€ 1$ of excess cash in a poorly governed firm is valued at only $€ 0.89$ while the value is $€ 1.45$ for a good governed firm. We show that poorly governed firms dissipate excess cash relatively quickly with a negative impact on their operating performance as a result.
\end{abstract}

Keywords: corporate governance, excess cash, take-over defences JEL Classification: G30, G32, G34

\footnotetext{
*Corresponding author: Marc Schauten, Department of Finance, Erasmus University Rotterdam, P.O. Box 1738, NL-3000 DR Rotterdam, The Netherlands, Tel: +31-10-4082367, Fax: +31-10-4089165, Email:schauten@few.eur.nl
} 


\section{$1 \quad$ Introduction}

We study the impact of corporate governance on the value of excess cash holdings by firms. Jensen (1986) argues that poorly monitored managers of publicly listed companies may waste free cash by investing money in value decreasing projects. In this context corporate governance could be of great value, if it protects shareholders against such mismanagement and irresponsible dissipation of cash.

In the absence of any market imperfections, the value of $€ 1$ on the bank account of firms should be valued equally by the capital market. However, in practice it is possible that management invests this $€ 1$ in a project that is worth less. These agency costs (see Jensen and Meckling, 1976) imply that the $€ 1$ held within the firm will be valued at a discount. The higher the probability of misallocation of cash holdings under management's control, the lower its market value. Good corporate governance could lower this probability of "wasting" by management and as such increase the value of firms' cash holdings.

If firms held only little amounts of cash, the sketched problem would be of minor importance. However, firms' cash holdings often are substantial. For the largest publicly listed European firms the sum of cash and cash equivalents was more than $13 \%$ of net assets (total assets minus cash) in the year 2000, while by 2005 this percentage had even increased to almost $17 \% .{ }^{1}$ For some individual firms these percentages are much higher. For example, cash holdings by $\mathrm{H} \& \mathrm{M}$ Hennes \& Mauritz from Sweden were 52\% and 103\% of net assets in 2000 and 2005, respectively. Firm's cash holdings also are very volatile. For example, AFC Ajax NV's cash holdings varied from 79\% in 1998 (the IPO year of ACF Ajax) via 18\% in 2000 to $27 \%$ in 2005 . If agency problems did not exist, there would be no valuation problem, even if the cash holdings are at such high and volatile levels as observed in practice. However, if shareholders fear misallocation of firm's cash by the incumbent management, the negative effects on the valuation of the firm can be huge.

A large body of literature explores the influence of corporate governance on the return on equity, firm value and firm performance, see Nesbitt (1994, 1995), Yermack (1996), Core et al. (1999), Gompers et al. (2003), Bauer et al. (2004), Bebchuk et al. (2005), Cremers and Nair (2005), Brown and Caylor (2006) and Core et al. (2006),

\footnotetext{
${ }^{1}$ Or $11.5 \%$ and $14.5 \%$ as percentage of total assets. The percentage of cash holdings for large publicly traded U.S. firms in 2003 was 13\%, see Dittmar and Mahrt-Smith (2007).
} 
among others. However, previous literature has not related the quality of corporate governance directly to the value of firm-level cash holdings. A notable exception is Pinkowitz et al. (2006), who study the relationship between cash holdings and firm value and the influence of governance on that relationship in an international context using a sample of firms from 35 countries. Pinkowitz et al. (2006) find that a dollar increase in cash holdings is worth roughly a dollar in countries with strong investor protection, but much less than a dollar in countries with poor investor protection. Other papers that deal with the value of cash are Faulkender and Wang (2006) and Pinkowitz and Williamson (2005). Both papers study the marginal value of cash but without taking corporate governance into consideration. Faulkender and Wang (2006) find amongst other things that the marginal value of cash holdings declines with the amount of cash holdings and with leverage, while Pinkowitz and Williamson (2005) document that the value of cash depends on both the investment and financing opportunity sets of the firm. Specifically, Pinkowitz and Williamson (2005) find that firms with good growth options have their cash valued at a premium relative to firms with poor growth prospects and that nearer financial distress and access to capital decreases the value of cash.

In this paper we focus on the effects of corporate governance on the value of excess cash, as this part of cash holdings is most easily accessible by management to derive "private benefits". As pointed out by Myers and Rajan (1998), it is easier to make cash disappear than to make a plant disappear. We argue that it is even easier to make excess cash disappear, as this part of the firm's cash holdings is not needed for other, economically motivated purposes such as financing new investment opportunities. We are interested in the valuation of excess cash by the market and especially in the influence of corporate governance on this valuation. A first attempt to examine this issue was made by Dittmar and Mahrt-Smith (2007) for U.S. firms. Dittmar and Mahrt-Smith (2007) find that governance has a positive effect on the value of excess cash and on the marginal value of total cash. In particular, the market value of excess cash for firms that have poor internal or external corporate governance in the form of extensive anti-takeover provisions and a low level of large shareholder monitoring, respectively, is found to be approximately one-half of the value of excess cash for firms that are well governed. Depending on the measure of corporate governance, the marginal value of $\$ 1.00$ held by a poorly governed firm varies between $\$ 0.42$ and $\$ 0.88$, compared to $\$ 1.27$ to $\$ 1.62$ for a well governed firm. 
Dittmar and Mahrt-Smith (2007) further show that poorly governed firms dissipate cash more quickly ${ }^{2}$ and in such a way that they experience lower operating performance. Explanations given by Dittmar and Mahrt-Smith (2007) for the lower value of (excess) cash for poorly governed firms are that these firms invest (more) money in low return projects ${ }^{3}$ and that excess cash may make managers "lazy" in the sense that it reduces their incentives to control costs, improve margins etc.

In contrast to Dittmar and Mahrt-Smith (2007), our study analyses the relation between four specific governance mechanisms and excess cash, i.e. Shareholder rights, Takeover defences, Disclosure and Board functioning. Our unique governance dataset provided by Deminor ${ }^{4}$ makes it possible to pinpoint which governance provisions influence the value of excess cash and which ones do not. In addition, we focus on the effects of corporate governance on the value of excess cash for a sample of large publicly listed European firms.

To determine the effects of corporate governance on the value of excess cash we follow the methodology of Dittmar and Mahrt-Smith (2007). We first use a cash model based on Opler et al. (1999) to determine the level of normal or "optimal" cash holdings and define excess cash as the difference between the actual cash holdings and the predicted normal cash holdings. We then employ value regressions as used in Fama and French (1998) and return regressions as used by Faulkender and Wang (2006) to determine the value of (positive) excess cash.

Our main empirical results can be summarized as follows. First, we find that the value of excess cash is positively related to the score for the corporate governance

\footnotetext{
${ }^{2}$ This finding is in accordance with Harford et al. (2008) who document a positive relation between corporate governance and cash reserves for U.S. firms. Cross-country (worldwide) evidence also shows that greater shareholder rights are associated with lower cash holdings, see e.g., Dittmar et al. (2003) and Pinkowitz et al. (2004).

${ }^{3}$ Harford et al. (2008) find that poorly governed U.S. firms dissipate their cash reserves more quickly primarily on value-reducing acquisitions than well governed firms, see also Harford (1999). Dittmar and Mahrt-Smith (2007), however, show that the value effects of excess cash and the reduction in operating performance cannot fully be explained by spending excess cash on acquisitions.

${ }^{4}$ Deminor offers since 1993 corporate governance ratings. Deminor was acquired by Institutional Shareholder Services (ISS) in 2005. ISS was acquired by RiskMetrics in 2007.
} 
measure of Takeover defences. ${ }^{5}$ In other words, excess cash held by firms with less anti-takeover provisions (low management rights) is valued higher than excess cash held by more protected firms (high management rights). Other corporate governance measures do not have a significant effect on the valuation of excess cash. For non-UK firms we find that the value of $€ 1$ of excess cash is only $€ 0.89$ for the lower Takeover defences quartile and $€ 1.45$ for the upper quartile. We interpret this finding as follows. The value of excess cash of firms with high management rights is relatively low, because the capital market cannot correct nor prevent the misuse of these cash holdings. Cash holdings of these firms are accordingly valued below "face value". On the other hand, firms with low management rights run the risk of being taken over if they destroy value (now or probably in the future) by investing in negative NPV projects or by operating extremely inefficient. Because of this threat of control over the amount of excess cash, the probability that it will be allocated wrongly is smaller and hence excess cash is valued higher.

Second, we find that firms with more anti-takeover provisions hold relatively less (excess) cash. In addition, those firms with high management rights spend their excess cash more quickly and on less profitable investments than firms with low management rights (that is, high governance scores). This indicates that indeed well governed firms operate under the fear of the capital market for misallocation of their excess cash holdings. The other governance mechanisms do not seem to be strong enough to convince the capital market that management will act in the shareholders' best interests.

The structure of this paper is as follows. In section 2 we discuss the Deminor governance data. In section 3 we present the models we use to estimate normal and excess cash levels and the relation between corporate governance and the value of excess cash. Data and summary statistics on cash are provided in the same section. In section 4 we report our empirical results. We conclude in Section 5.

\footnotetext{
${ }^{5}$ Anti-takeover provisions that prevent a successful acquisition by a bidder are seen as an indication of poor corporate governance. This is comparable with the interpretation of the Gompers et al. (2003) measure.
} 


\section{Corporate governance data}

We use Deminor ratings to measure the quality of firm-level corporate governance. These ratings cover firms included in the FTSEurofirst 300 Index for the years 20002004. The Deminor ratings are based on 300 different governance indicators that refer to internationally accepted standards, as outlined by the International Corporate Governance Network (ICGN), the World Bank, the Organisation for Economic Cooperation and Development (OECD) and the Conference Board (Deminor Rating, 2004). ${ }^{6,7}$ The different indicators or criteria can be classified into four categories: rights and duties of shareholders (referred to as Shareholder rights in the remainder of the paper); range of takeover defences (Takeover defences); disclosure on financial matters and corporate governance (Disclosure); and Board structure and functioning (Board). For each category a rating is available on a scale from 1 to 10 , where a score of 10 (1) corresponds to the best (worst) possible governance quality. The total governance score is simply the sum of the rating scores of the four categories.

The first category of governance criteria, Shareholder rights, concerns the question whether shareholders can exert sufficient power to determine corporate action. The score is based on i) the 'one share - one vote - one dividend' principle; ii) access to and voting procedures at general meetings, and iii) maintenance of pre-emptive rights. Firms that respect the control and ownership roles of shareholders, score high on the 'one share - one vote - one dividend' principle. Deminor evaluates whether companies submit voting issues that are perceived as particularly significant to the general meeting of shareholders and assesses the voting structure. Furthermore, companies should respect the pre-emptive rights of the existing shareholders as these stakeholders would like to prevent dilution of their voting or economic power.

The second category, Takeover defences, examines the extent to which the firm attempts to decrease the likelihood of a hostile takeover through the adoption of anti-

\footnotetext{
${ }^{6}$ The Deminor rating methodology further takes into consideration the main orientations chosen by national Codes of Best Practice, among which: the Combined Code in the UK (2003); the Vienot reports and the Bouton report in France (1995, 1999 and 2002); the Kodex in Germany (2002); the Preda Code in Italy (1999); the Tabaksblat Code in The Netherlands (2003).

${ }^{7}$ About the same criteria are used by Standard \& Poor's for their corporate governance score (Standard $\&$ Poor's, 2002). This, taken together with the fact that all of these institutions have more or less the same ideas concerning good corporate governance, leads us to conclude that the Deminor rating is a representative measure for the quality of a firm's corporate governance.
} 
takeover provisions. Deminor examines the presence and strength of anti-takeover devices such as poison pills, golden parachutes, core shareholdings and extensive cross-shareholdings. To achieve a high score for this aspect of governance, the range of takeover defences should lead to a favourable bidding process and not preclude the success of a takeover attempt per se.

The third category, Disclosure, measures whether shareholders are able to obtain convenient and comprehensive information about the company's financial matters as well as its governance characteristics. Deminor analyses for instance the quantity and quality of non-financial information, such as the diversity and independence of board members, board committees, accounting standards and information on major shareholders of the company.

The fourth category, Board, measures issues relating to the governance of a Board, such as the presence of independent directors, division between the role of Chairman and Chief Executive and the election of the board.

- insert Table 1 about here -

Table 1 presents descriptive statistics of the governance scores for our sample, comprising 271 large European firms over the period 2000-2004 (905 firm-year observations). We observe a positive trend in the overall governance scores, as well as in the sub-scores. The average total score in 2000 is equal to 19.02, which gradually increases to 23.84 in 2004 . This trend is in line with the increased attention paid to governance structures by policy makers, see footnote 6 for a list of National Codes of Best Practice, and the subsequent firm actions to improve their corporate governance. ${ }^{8}$

- insert Table 2 about here -

Tables 2 and 3 present the governance scores by country and industry, respectively. The extensive investor rights in common law countries such as the United Kingdom and Ireland (LaPorta et al., 1998) are confirmed by the relatively high governance scores for firms in these countries. The average scores for the United

\footnotetext{
${ }^{8}$ We note that the cross-section of firms varies across the different years in the sample period. We find a similar positive trend when restricting the sample to those firms for which ratings are available over the complete sample period.
} 
Kingdom and Ireland are equal to 27.93 and 28.09, respectively. The average scores for these countries are higher than the overall European average for all four categories, with the difference being most pronounced for Takeover defences. Interestingly, even when leaving the UK and Ireland out of consideration, the crosscountry variation in the average score for Takeover defences is considerably larger than for the other three governance categories, ranging between 0.25 for Portugal and 5.64 for Finland. Also note that the number of observations varies widely across countries, from just 2 for Luxembourg to 264 for the UK.

- insert Table 3 about here -

Across industries, we observe from Table 3 that Construction, Metal producers, Metal product manufacturers and Tobacco have relatively high total governance scores. These relatively high scores are (at least partly) due to the UK country effect given that 10 of the 32 Construction observations, 14 of the 15 Metal producers observations, 5 of the 10 Metal product manufacturers observations and 14 of the 19 Tobacco observations concern UK (or Irish) firms. However, controlling for country (and year effects), we still find higher total governance scores for the Construction, Metal product manufacturers and Tobacco industries. ${ }^{9}$

\section{$3 \quad$ Models and data}

\subsection{Models}

To determine the level of excess cash we first need to estimate the level of normal or "optimal" cash holdings for a firm. The regression model that we use for this purpose includes variables that are used in prior literature on the determinants of cash holdings in imperfect capital markets, including Kim et al. (1998), Opler et al. (1999), Ferreira and Vilela (2004), and Ozkan and Ozkan (2004). Our main specification for the determination of the level of normal cash holdings is given by

\footnotetext{
${ }^{9}$ To control for country and year effects we regress the total governance scores on country dummies and year dummies and compute industry averages for the residuals from this model. In that case, besides Construction, Metal product manufacturers and Tobacco also Automotive, Chemicals, Electrical, Electronics, Machinery and equipment and Textiles have mean scores above the overall average. Below average scores are found for Aerospace, Drugs, cosmetics and health care, Paper and Transportation.
} 


$$
\begin{aligned}
& \frac{\text { Cash }_{i, t}}{N A_{i, t}}=\beta_{0}+\beta_{1} \operatorname{Re} \text { alAssets }_{i, t}+\beta_{2} \frac{C F_{i, t}}{N A_{i, t}}+\beta_{3} \frac{N W C_{i, t}}{N A_{i, t}}+\beta_{4} \operatorname{Sigma}_{i, t}+\beta_{5} \frac{M V_{i, t}}{N A_{i, t}} \\
& +\beta_{6} \frac{R D_{i, t}}{N A_{i, t}}+Y F E+F F E+\varepsilon_{i, t}
\end{aligned}
$$

where (data source codes are listed in Appendix A): Cash $_{i, t}=$ Cash and Cash Equivalents of firm $i$ at time $t, N A_{i, t}=$ Net Assets (= Total Assets minus Cash and Cash Equivalents) at time $t$, RealAssets Ret $=$ Total Assets at time $t$ inflated to 2005 prices, $N W C_{i, t}=$ Net Working Capital $(=$ Working Capital minus Cash and Cash Equivalents) at time $t, \operatorname{Sigma}_{i, t}=$ industry average of prior 6 year standard deviation of $C F / N A, M V_{i, t}=$ Year-End Market Capitalization plus Total Debt at time $t, R D_{i, t}=$ Research and Development expenses (set to 0 if missing) over year $t$, YFE = Year Fixed Effects, and $F F E=$ Firm Fixed Effects.

Our main specification includes measures for size, cash flow, cash substitutes, risk, growth options, and costs of financial distress. These variables are commonly used as proxies for the determinants of normal cash holdings that arise through the transactions motive and the savings motive, where the latter refers to the incentive to accumulate cash for financing new investment opportunities when external finance is costly, see Opler et al. (1999). Size plays a double role, in the sense that it acts both as a measure of the transactions motive as well as a proxy for access to financial markets. Cash flow and net working capital are interpreted as substitutes for cash. The market-to-book ratio and R\&D expenses serve as proxies for growth opportunities, information asymmetry, and financial costs of distress. We expect a negative coefficient for size and net working capital and a positive coefficient for growth opportunities, R\&D expenses and risk. The expected sign for cash flow is positive according to the pecking order theory and negative according to the trade-off theory. The year dummies are included to account for macroeconomic factors which may influence overall demand and supply of liquidity. The firm fixed effects control for the fact that due to idiosyncratic reasons some firms may consistently hold higher or lower normal cash levels than required for economic reasons. Excess cash is defined as the difference between the actual cash holdings and the estimated normal cash holdings, that is, the residual from (1). Following Dittmar and Marht-Smith (2007), however, we do include the firm fixed effects as part of excess cash, as this does not reflect the generally accepted economic reasons for holding cash, such as operational 
needs or future investments. ${ }^{10}$ As Dittmar and Marht-Smith (2007), we include the year fixed effects as part of excess cash as well.

Following Dittmar and Mahrt-Smith (2007), to determine the effect - if any - of corporate governance on the value of excess cash, we estimate value regressions based on Fama and French (1998). The dependent variable is the market-to-book ratio, which is taken as a measure of total firm value (equity and debt). The regression model includes control variables representing factors that are likely to affect investors' expectations of future net cash flows. Specifically, the control variables are past changes, future changes, and current levels of earnings, $R \& D$ expenses, dividends, interest expenses, as well as past and future net assets, and future changes of the market value of the firm. Given that we aim to measure the effect of excess cash on firm value and, in particular, the influence of corporate governance on this effect, we also include excess cash (scaled by net assets) and the interaction between the governance score and excess cash. In addition, the governance score itself is included to control for the fact that corporate governance may affect firm value also through other channels besides excess cash. In sum, for each governance measure, i.e. the Total governance score and the sub-scores on Shareholder rights, Takeover defences, Disclosure and Board, we estimate the following regression:

$$
\begin{aligned}
& \frac{M V_{i, t}}{N A_{i, t}}=\beta_{0}+\beta_{1} \frac{E_{i, t}}{N A_{i, t}}+\beta_{2} \frac{d E_{i, t}}{N A_{i, t}}+\beta_{3} \frac{d E_{i, t+1}}{N A_{i, t}}+\beta_{4} \frac{R D_{i, t}}{N A_{i, t}}+\beta_{5} \frac{d R D_{i, t}}{N A_{i, t}} \\
& +\beta_{6} \frac{d R D_{i, t+1}}{N A_{i, t}}+\beta_{7} \frac{D i v_{i, t}}{N A_{i, t}}+\beta_{8} \frac{d D i v_{i, t}}{N A_{i, t}}+\beta_{9} \frac{d D i v_{i, t+1}}{N A_{i, t}}+\beta_{10} \frac{I_{i, t}}{N A_{i, t}}+\beta_{11} \frac{d I_{i, t}}{N A_{i, t}} \\
& +\beta_{12} \frac{d I_{i, t+1}}{N A_{i, t}}+\beta_{13} \frac{d N A_{i, t}}{N A_{i, t}}+\beta_{14} \frac{d N A_{i, t+1}}{N A_{i, t}}+\beta_{15} \frac{d M V_{i, t+1}}{N A_{i, t}}+\beta_{17} \frac{X C_{a s h} h_{i, t}}{N A_{i, t}} \\
& +\beta_{16} G O V_{i, t}+\beta_{18} G O V_{i, t} \frac{X C_{a s h}, t}{N A_{i, t}}+Y F E+F F E+\varepsilon_{i, t}
\end{aligned}
$$

where $d X_{i, t}$ indicates a change in variable $X$ from time $t-1$ to $t$, and $M V_{i, t}=$ Year End Market Capitalization plus Total Debt at time $t, N A_{i, t}=$ Net Assets (= Total Assets minus Cash and Cash Equivalents) at time $t, E_{i, t}=$ Earnings Before Interest and Taxes (EBIT) over year $t, R D_{i, t}=$ Research and Development expenses (set to 0 if missing) over year $t, D i v_{i, t}=$ Common Dividends over year $t, I_{i, t}=$ Interest Expenses over year $t, \operatorname{Cash}_{i, t}=$ Excess Cash (= Total Cash and Cash Equivalents minus the normal level of cash from equation (1)) at time $t, G O V_{i, t}=$ Governance measure, which is the

\footnotetext{
${ }^{10}$ For example, Foley et al. (2007) show that US multinationals hold cash, in part, as a consequence of the tax costs associated with repatriating foreign income.
} 
governance score for Shareholder rights, Takeover defences, Disclosure or Board, or the overall score for these four categories, $Y F E=$ Year Fixed Effects and $F F E=$ Firm Fixed Effects. We include year fixed and firm fixed effects to capture macroeconomic and time trend effects and unobserved heterogeneity and fixed industry effects, respectively.

Because we are interested in the value of a firm's cash 'surplus' we estimate the value regression using only those firm-year observations for which excess cash is positive. The coefficient of key interest in model (2) obviously is $\beta_{18}$. If the quality of corporate governance positively influences the value of excess cash, this coefficient for the interaction term between the governance score and excess cash should be positive.

In addition to the value regression model as given in (2), we estimate an alternative model where we focus on value effects of changes in excess cash instead of levels. In this model, which is based on Faulkender and Wang (2006), the dependent variable is the excess stock return, while the regressors of interest are the change in excess cash and its interaction with the governance score. The main specification of this return model is given by:

$$
\begin{aligned}
& r_{i, t}-R_{i, t}=\beta_{0}+\beta_{1} \frac{X \operatorname{Cash}_{i, t-1}}{M E_{i, t-1}}+\beta_{2} * \frac{d E_{i, t}}{M E_{i, t-1}}+\beta_{3} * \frac{d N A_{i, t}}{M E_{i, t-1}}+\beta_{4} * \frac{d R D_{i, t}}{M E_{i, t-1}} \\
& +\beta_{5} * \frac{d I_{i, t}}{M E_{i, t-1}}+\beta_{6} * \frac{d D i v_{i, t}}{M E_{i, t-1}}+\beta_{7} \frac{X \operatorname{Cash}_{i, t-1}}{M E_{i, t-1}}+\beta_{8} * L_{i, t}+\beta_{9} * \frac{N F_{i, t}}{M E_{i, t-1}} \\
& +\beta_{10} *\left(\frac{X \operatorname{Cash}_{i, t-1}}{M E_{i, t-1}} * \frac{d X \operatorname{Cash}_{i, t}}{M E_{i, t-1}}\right)+\beta_{11} *\left(L_{i, t} \frac{d X \operatorname{Cash}_{i, t}}{M E_{i, t-1}}\right)+\beta_{12} *\left(G O V_{i, t} \frac{d X \operatorname{Cash}_{i, t}}{M E_{i, t-1}}\right) \\
& +\beta_{13} * G O V_{i, t}+Y F E+F F E+\varepsilon_{i, t}
\end{aligned}
$$

where, $d X_{i, t}$ indicates a change in $X$ from time $t-1$ to $t$, and $r_{i, t}=$ stock return over year $t, R_{i, t}=$ market model return over year $t$ (we estimate the market model using the year $t-1$ arithmetic returns derived from the daily stock return index of each firm and the FTSEurofirst 300 Index), XCash ${ }_{i, t}=$ Excess Cash (= Total Cash and Cash Equivalents minus the normal level of cash from equation (1)) at time $t, M E_{i, t}=$ Market Value equity (= Market Capitalization) at time $t, E_{i, t}=$ Earnings Before Interest and Taxes (EBIT) over year $t, N A_{i, t}=$ Net Assets $(=$ Total Assets minus Cash and Cash Equivalents) at time $t, R D_{i, t}=$ Research and Development expenses (set to 0 if missing) over year $t, L_{i, t}=$ Leverage ( $=$ Total $\operatorname{Debt}_{\mathrm{i}, \mathrm{t}} /\left(\right.$ Total Debt $\left.\left._{i, t}+M E_{i, t}\right)\right)$ at time $t$, $N F_{i, t}=$ New Finance $(=$ Net New Equity Issues (Sale of Common \& Preferred stock minus Purchase of Common \& Preferred Stock) + New Debt Issues (Long Term Debt 
Issuance minus Long Term Debt Reduction)) over year $t, G O V_{i, t}=$ Governance measure and $Y F E=$ Year Fixed Effects and $F F E=$ Firm Fixed Effects. In addition to the excess return we will also use the percent change in market capitalization $\left(M E_{i, t^{-}}\right.$ $\left.M E_{i, t-1}\right) / M E_{i, t-1}$ as dependent variable in (3).

The control variables in the return regression as given in (3) account for firmspecific characteristics that may be correlated with both returns and cash holdings due to changes in profitability $\left(E_{i, t}\right)$, investment $\left(N A_{i, t}\right.$ and $\left.R D_{i, t}\right)$ and financing $\left(I_{i, t}, D i v_{i, t}\right.$, $L_{i, t}$ and $N F_{i, t}$ ), see Dittmar and Mahrt-Smith (2007).

Again we are interested in the value of a cash surplus, and therefore we estimate the return regression on those firm-year observations with positive excess cash at $t-1$. The key coefficient in this model is $\beta_{12}$. If the quality of one or more corporate governance measures positively influences the value of excess cash, the coefficient for the interaction term between the governance score and the change in excess cash should be positive. Using the estimates of (3) we can also determine the difference in marginal value of $€ 1$ held by poorly governed firms compared to well governed firms.

\subsection{Data}

Our sample consists of publicly traded European firms that were included in the FTSEurofirst 300 Index at some point between 2000 and 2004 and were given a governance rating by Deminor. We retrieve data items for these firms-as far as available-for the longer period from 1990 to 2005. Firm data is obtained from the Worldscope database, Datastream and Thomson Financial Database. Variable identifiers are listed in Appendix A. We exclude financial firms (Worldscope Industry Group 4300), because their business involves inventories of marketable securities that are included in cash, and because of their need to meet statutory capital requirements. ${ }^{11}$ Some firms were excluded from the sample due to data problems. ${ }^{12}$

\footnotetext{
${ }^{11}$ We do not exclude the Utilities sector as in Dittmar and Mahrt-Smith (2007) since this would seriously limit the size of our sample.

${ }^{12}$ No reliable data could be obtained for Allied Domecq (FIN), Sonera (FR), Orange (FR), Pchiney (FR), Rexel (FR), Telecom Italia Mobile (IT) and Terra Networks (SP). Due to mergers also no reliable data could be obtained for Royal Dutch Shell and LogicaCMG (UK). In addition, we exclude Dampskbselsskabet Svendborg for this company was incorporated twice, with different governance ratings. We also exclude Vivendi Environment for this company is a subsidiary of Vivendi which also has a Deminor rating.
} 
As discussed in Section 2, various aspects of the corporate governance quality of the firms is measured by means of the Deminor ratings, which are available for the years 2000-2004. Year $t$ ratings are published at the beginning of year $t+1$.

To mitigate the impact of outliers on our results, we winsorize all variables except the governance scores at the mean plus or minus three times the standard deviation. In case of ratios, only the ratio is winsorized. The effects of price inflation are handled by inflating the variables to 2005 prices, using the Harmonized Index of Consumer Prices (HICP) obtained from the European Central Bank.

We estimate the normal cash model as given in (1) over the years 1990-2005, and both the value regression in (2) and the return regression in (3) over the years 20002004. The maximum number of firm-year observations for the period 1990-2005 is 3,831 , while the maximum number for the period 2000-2004 is 1,340 . The sample includes observations for 271 unique firms.

- insert Table 4 about here -

Table 4 shows the number of firm-year observations and summary statistics for the cash-to-assets ratio per country for the period 1990-2005. The overall mean of the cash-to-assets ratio (Cash and Cash Equivalents divided by Net Assets) is 15.6\%. Although for most countries the average cash-to-assets ratio is close to this overall mean, for some countries it deviates considerably. Switzerland and Ireland have relatively high average cash-to-assets ratios of $26.3 \%$ and $45.8 \%$, respectively. Countries with relatively low cash-to-assets ratios are Austria, Portugal and Spain with averages equal to $3.8 \%, 6.0 \%$ and $9.5 \%$, respectively. According to Ferreira and Vilela (2004), this cross-country heterogeneity can be a consequence of different accounting standards as well as different institutional environments, including bankruptcy laws, the state of development of capital markets, and patterns of corporate governance. ${ }^{13}$

\footnotetext{
${ }^{13}$ We note that these cross-country differences in our sample should be interpreted with care, as the number of observations for countries such as Ireland, Austria and Portugal are limited. Nevertheless, Ferreira and Vilela (2004) also report a relatively high average cash-to-assets ratio for Ireland and relatively low averages for Austria and Portugal, see also Dittmar et al. (2003). Our overall average ratio of $15.6 \%$ is rather close to the mean of $14.8 \%$ reported by Ferreira and Vilela (2004) for a sample of firms from EMU countries over the period 1987-2000.
} 
Appendix B presents the same summary statistics for the cash-to-assets ratio per country for the shorter period 2000-2004 that is used to estimate the value and return regressions. Generally, these correspond quite closely to the numbers in Table 4.

- insert Table 5 about here -

Table 5 presents summary statistics for the cash-to-assets ratio by industry for the period 1990-2005, while Appendix C shows these for the period 2000-2004. We observe substantial differences across industries, with the mean ratio ranging from a minimum of 0.034 for Paper to a maximum of 0.283 for Drugs, cosmetics and health care, and Electronics. As far as these industry effects are not accounted for by our economic regressors in the normal cash model and as long as they are constant over time, they will be captured by the firm specific dummies included in (1).

\section{$4 \quad$ Empirical results}

\subsection{Cash model}

The results of the cash model are presented in Table 6. Column 1 presents the results of our main specification as given in (1). The results of this model are used to determine excess cash. In columns 2 and 3, we consider model variations based on Opler et al. (1999) and Ferreira and Vilela (2004), which include Leverage (Total Debt divided by Net Assets), a Dividend dummy (the dummy equals 1 if a firm pays out dividend and 0 otherwise) as well as Capital Expenditures (Capital Expenditures divided by Net Assets). We find that cash-to-assets increases with investment opportunities (market to book), the magnitude of the cash flow (Cash Flow / Assets), industry risk (sigma industry) and R\&D expenditures (R\&D / Assets). Cash-to-assets decreases with liquidity (Net Working Capital / assets). The relation with leverage is significantly positive, while there is neither a significant relation with capital expenditure nor with dividend and size. These findings are mostly consistent with previous empirical studies on the determinants of cash holdings (Ferreira and Vilela, 2004, Opler et al., 1999, Ozkan and Ozkan, 2004, Dittmar and Mahrt-Smith 2007).

- insert Table 6 about here - 


\subsection{Corporate governance and the value of excess cash}

We estimate our value regression as given in (2) on all firm-year observations with positive excess cash at time $t$. Table 7 presents the results. In column 1, we use the sum of the four separate governance scores as governance measure, while in columns 2-5 we use the sub-scores for Shareholder rights, Takeover defences, Disclosure and Board, respectively. We find that good governance, as measured by the total score, has a significantly positive effect on the value of excess cash. The results in columns 2-5 reveal that this relation is driven purely by the Takeover defences governance measure. The coefficient on the interaction term between excess cash and this governance measure is positive (0.508) and significant (p-value of 0.038). ${ }^{14} \mathrm{We}$ interpret this outcome as follows. The management of firms with a low score for Takeover defences have good possibilities to prohibit being acquired by a hostile bidder. The 'management rights' for these firms are high. If these firms hold excess cash and destroy value because of negative NPV projects (such as overpaid acquisitions) or inefficiency, the capital market is in the worst case not able to take over the firm and to disgorge the cash in order to prevent it from being wasted. The value of their excess cash is accordingly, relatively low. However, if well governed firms hold excess cash, the capital market can, if she wishes, take over the firm and extract the cash if necessary. Because of this threat of control over the amount of excess cash, the probability that it will be allocated wrongly is smaller and, hence, excess cash is valued higher.

- insert Table 7 about here -

In Table 8, where the governance score is Takeover defences, we report the results of alternative specifications. In column 1, we include normal cash as obtained from the cash model as extra control variable, while in column 2 we also include the interaction term between normal cash and the corporate governance measure Takeover defences. As expected, the coefficient on the additional interaction term is insignificant. Normal cash as part of cash reserves for daily operations and investments is not valued differently between well and poorly governed firms.

\footnotetext{
${ }^{14}$ In untabulated results, we use excess cash as estimated by the models in columns 2 and 3 in Table 6. The results confirm the finding that Takeover defences have a significant and positive influence on the value of excess cash.
} 
However, the interaction term on corporate governance and excess cash remains positive and significant, in both columns 1 and 2. In columns 3 and 4, we exclude insignificant control variables from our main value specification (column 3 in Table 7). Our results are robust for these alternative specifications.

- insert Table 8 about here -

Note that since we use the $\mathrm{M} / \mathrm{B}$ ratio as proxy for growth opportunities in our cash model and as proxy for firm value in our value model, it is plausible that the excess cash variable in the value model is related to firm value because of investment opportunity hedging needs rather than direct value implications. However, our coefficient of interest is not the coefficient for Excess cash (in total) but primarily the coefficient on the interaction term between excess cash and governance. Although the total effect of excess cash on the value of the firm could be biased by the use of $\mathrm{M} / \mathrm{B}$ as proxy for growth in the cash model, we assume this is not the case for the coefficient of the interaction term (see Dittmar and Mahrt-Smith, 2007). ${ }^{15}$

Governance may be endogenously determined with value as well (see Dittmar and Mahrt-Smith, 2007). In untabulated results, we estimate our value regression using the 2 year lagged governance score to avoid this endogeneity issue. The results confirm that Takeover defences have a significant and positive impact on the value of excess cash holdings.

As an althernative way to determine the effects of corporate governance on the value of excess cash and to directly assess the marginal value of excess cash holdings we estimate the return model as given in (3). Table 9 presents the results. Given the results from the value regressions, we expect that the governance measure Takeover defences significantly increases the value of excess cash. Columns 1-3 present the results where we use the percent increase of market capitalization as dependent variable, while columns 4-6 present results where the market model excess return is the dependent variable.

\footnotetext{
${ }^{15}$ If we estimate the cash model with the three year lagged sales growth instead of the $\mathrm{M} / \mathrm{B}$ ratio as proxy for growth opportunities or without proxy for growth opportunities, we still find a significantly positive coefficient for the interaction term between excess cash and governance measure Takeover defences. The results of these alternative cash models are consistent with the results presented in Table 8 and Table 9.
} 
- insert Table 9 about here -

The results in model [1] confirm that the stock market places a higher value on excess cash for well governed firms relative to poorly governed firms. If we split the sample in non-UK and UK firms then we find that the coefficient is highly significant for non-UK firms. ${ }^{16}$

The results in column 4 with excess return as dependent variable do not indicate that governance pays off. However, if we again split the sample in non-UK and UK firms, we find a highly significant positive coefficient on the interaction term GOV t.d. $\mathrm{x} \Delta \mathrm{L} \mathrm{XCash} / \mathrm{ME}$ for the non-UK firms. This implies that for non-UK firms, the marginal value of excess cash is higher for well governed firms than for poorly governed firms. For the non-UK firms we calculate the marginal value of $€ 1$ of excess cash, which is equal to the sum of the coefficient on the change in excess cash $(\Delta \mathrm{L}$ $\mathrm{XCash}$ ) and the coefficients on the interaction variables that include the change in excess cash times the 'in sample means' of the regressors interacting with the change in excess cash. The results are remarkable. The marginal value of $€ 1 \mathrm{XCash}$ for the non-UK firms following model [5] then is equal to $€ 1.14$ on average. However, the value of $€ 1$ excess cash is only $€ 0.89$ for the lower Governance t.d. quartile and $€ 1.45$ for the upper quartile. This finding is consistent with Dittmar and Mahrt-Smith (2007).

\subsection{Corporate governance and the use of excess cash}

The results from both the value regressions and returns regressions indicate that excess cash held by poorly governed firms in the form of extensive takeover defences is valued at a discount. As discussed in the introduction, previous research for US firms has documented that poorly governed firms hold relatively high levels of (excess) cash and spend their excess cash more quickly than well governed firms. We

\footnotetext{
${ }^{16}$ The difference in the results between non-UK and UK firms could imply that the relevance of Shareholder rights for the valuation of unexpected changes in the level of excess cash is higher for nonUK firms than for UK firms. Alternatively, it could be that for this small sample of UK-firms with in general high scores for governance component Takeover defences, it is difficult to capture the effect of governance on the value of excess cash.
} 
conclude this section by examining whether these findings also apply to our sample of European firms.

First, to analyse the influence of the quality of corporate governance on the level of excesss cash holdings, we return to the cash regression model in (1). We reestimate this model, but including the corporate governance scores. Results are reported in columns 4 and 5 of Table 6 . Actual cash holdings are positively related to the total governance rating (see column 4), which is driven by the government measure Takeover defences (see column 5). Note that the positive coefficient for Takeover defences means that firms with less anti-takeover provisions hold more cash than firms with more takeover defences. Since we do not include governance variables in our main specification for normal cash holdings as given in (1), this result implies that firms with a high score on the corporate governance measure Takeover defences hold more excess cash. ${ }^{17}$ This result is consistent with Harford et al. (2008) who find that firms in the U.S. with weaker corporate governance have smaller cash reserves. $^{18}$

Harford et al. (2008) suggest that firms with weaker corporate governance dissipate their cash reserves more quickly than do managers of firms with stronger governance, see also Dittmar and Mahrt-Smith (2007). To analyze whether similar differences in excess cash spending between well and poorly governed firms show up in our sample of European firms, we consider those firm-year observations with both positive excess cash at time $t-1$ and a decline in excess cash between $t-1$ and $t$. Using those observations we regress the change in excess cash on the four governance scores including year fixed and firm fixed effects, that is:

$$
\begin{aligned}
& \frac{X_{\text {Cash }_{i, t}-\text { Xcash }_{i, t-1}}}{\text { Assets }_{i, t-1}}=\beta_{0}+\beta_{1} \text { ShareholderRights } \beta_{2} \text { TakeoverDefences } \\
& +\beta_{3} \text { Disclosure }+\beta_{4} \text { Board }+F F E+Y F E+\varepsilon_{i, t}
\end{aligned}
$$

where Assets $_{i, t}=$ Total Assets minus Cash and Cash Equivalent at time $t$ - 1 .

\footnotetext{
${ }^{17}$ If we regress excess cash on the four corporate governance scores, including firm fixed and year fixed effects, we find a significant coefficient for governance measure Takeover defences (coefficient is 0.005 and a p-value of 0.000 ) and insignificant coefficients for the other three governance measures.

${ }^{18}$ Our results contrast with Dittmar et al. (2003) who find that corporations in countries (worldwide) where shareholder rights are not well protected hold up to twice as much cash as corporations in countries with good shareholder protection.
} 
The results are presented in column 1 of Table 10. The positive coefficient for Takeover defences indicates that the reduction in excess cash is indeed higher for firms with a low takeover defences governance score. Put differently, firms with a high score for Takeover defences, spend their excess cash less quickly. This finding is in agreement with the results by e.g. Dittmar and Mahrt-Smith (2007) and Harford et al. (2008). ${ }^{19}$ In column 2 we present the results where the change in Excess cash is normalized by the market value of equity at time $t-1$. The results are similar as in column $1 .^{20}$

- insert Table 10 about here -

The finding that poorly governed firms spend their excess cash more quickly than well governed firms need not necessarily be a bad thing. On the contrary, given that excess cash is not held for economically motivated purposes, spending it may be valued positively. What is crucial, of course, is how management uses the available excess cash. The results in Tables 7 and 8, indicating that the value of excess cash for poorly governed firms is substantially lower, suggest that those firms may not be spending their money in the best possible way. Following Dittmar and Marht-Smith (2007), we examine this issue indirectly by analyzing the return on asssets (ROA) for those firms spending part of their excess cash. Specifially, we estimate the following regression $^{21}$ :

$$
\begin{aligned}
& \operatorname{ROA}_{i, t}=\beta_{0}+\beta_{1} \frac{\operatorname{XCash}_{i, t-1}}{\operatorname{Assets}_{i, t-1}}+\beta_{2} \text { GOV }_{i, t-1}+\beta_{3} \frac{\operatorname{XCash}_{i, t-1}}{\operatorname{Assets}_{i, t-1}} G_{i, t-1} \\
& +\beta_{4} L N\left(\operatorname{Re} \text { alAssets }_{i, t}\right)+\beta_{5} \frac{P P E_{i, t}}{\text { Assets }_{i, t}}+\beta_{6} R O A_{i, t-1}+Y F E+F F E+\varepsilon_{i, t}
\end{aligned}
$$

\footnotetext{
${ }^{19}$ Pinkowitz (2000) finds that the probability that a firm will be acquired decreases with cash and states that managers may hold cash to entrench themselves at shareholder's expense. Following this line of reasoning, firms with a high score for Takeover defences may hold higher levels of cash to protect themselves from being targeted.

${ }^{20}$ To analyze whether governance influences the decision to accumulate excess cash, we estimate the regression in (4) for the sample of firm-year observations with both negative excess cash at time $t$-1 and an increase in excess cash between $t-1$ and $t$. We do not find any relation between the accumulation of excess cash and governance. This finding is in accordance with Dittmar and Mahrt-Smith (2007).

${ }^{21}$ The equation is similar to equation (3) of Dittmar and Mahrt-Smith (2007) and controls for size, asset structure and lagged industry adjusted ROA.
} 
where $R O A i, t=$ EBIT in year $t$ divided by Assets at time $t$ minus Cash and Cash Equivalents at time $t$ minus industry average $R O A, X \operatorname{Cash}_{i, t}=$ Excess Cash at time $t(=$ Total Cash and Cash Equivalents minus the normal level of cash from equation (1) at time $t), G O V_{i, t-1}$ is the governance score takeover defences at $t-1$, Assets $s_{i, t-1}=$ Total Assets minus Cash and Cash Equivalents at time $t, \operatorname{Re} a l N A_{i, t}=$ Total Assets at time $t$ inflated to 2005 prices, $P P E_{i, t}=$ Property, Plant and Equipment at time $t$.

We are interested in the coefficient of the interaction term between lagged excess cash and the lagged governance measure. A positive coefficient $\left(\beta_{3}\right)$ on this interaction term indicates that for every euro of excess cash held at time $t$ - 1 , firms with bad corporate governance who used up excess cash experience a lower ROA in that year compared to firms with good corporate governance. The results in Table 11 show that this indeed is the case, cf. Dittmar and Mahrt-Smith (2007). The coefficient on the interaction term is significantly positive except - surprisingly - for the corporate governance measure Takeover defences (see column 3). However, if we replace $\mathrm{ROA}_{i, t}$ by $\mathrm{ROAi}_{\mathrm{,t}+1}$ we find a significantly positive coefficient for takeover defences, while the coefficients of the other governance scores remain significantly positive. $^{22}$

- insert Table 11 about here -

The lower value of excess cash held by poorly governed firms could thus be explained by the negative influence of their spending on the ROA. Because of the lack of corporate control, managers of firms with high management rights can potentially destroy value. If these firms had no anti-takeover provisions, the capital market would probably have made corrective actions by taking over control in order to prevent future wasteful spending. ${ }^{23}$

\footnotetext{
${ }^{22}$ If we regress acquisitions divided by net assets on the lagged amount of excess cash and on total governance - including fixed firm and fixed year effect - and we restrict the sample to firms with positive lagged excess cash, we find no relation between acquisitions and the quality of corporate governance. And we do not find evidence that acquisitions have a significant impact on the return on assets.

${ }^{23}$ Faleye (2004) investigates the role of proxy fights in relation to cash holdings. Faleye (2004) finds that proxy fight targets hold $23 \%$ more cash than comparable firms and that following a contest, executive turnover and special cash distributions to shareholders increase.
} 


\section{Conclusions}

In this paper we examine the relation between the quality of corporate governance and the value of excess cash for large European firms (FTSEurofirst 300). We use Deminor ratings for Shareholder rights, Takeover defences, Disclosure and Board as proxies for the quality of corporate governance. Following the approach of Dittmar and Mahrt-Smith (2007) we first estimate a cash model to determine the level of normal cash holdings and subsequently the level of excess cash. Next, we analyze the influence of governance on the value of excess cash. We find that the value of excess cash is positively related to the governance Takeover defence score only. For non-UK firms we find that the value of $€ 1$ of excess cash is only $€ 0.89$ for the lower Takeover defences scores quartile and $€ 1.45$ for the upper quartile. Firms that (potentially) invest in negative NPV projects, and cannot be corrected by being taken over, are valued lower accordingly. We find no relation between the value of excess cash and the quality of firms' corporate governance categories Shareholder rights, Disclosure and Board. Given our empirical results, only the market for corporate control seems strong enough to prevent managers from wasting excess cash.

The level of excess cash is also related inversely to the extent of takeover defences, while firms with positive excess cash and a low quality of corporate governance spend a larger part of their excess cash than firms with a high quality of corporate governance. We further find that governance positively influences the ROA in the years after the year of spending. If we assume that projects that lower the ROA are negative NPV projects, the "value destructive investing behaviour" of poorly governed firms could explain the value differential of excess cash between well and poorly governed firms. 
Appendix A Variables and variable codes

The first column shows the variable name and the second columns shows the database identifiers. WS stands for Worldscope database. DS stands for Datastream database, TF stands for Thomson Financial Database.

Table A.1 Data variables identifiers

\begin{tabular}{ll}
\hline Variable & Identifier \\
\hline Acquisitions & WS.NetAssetsFrAcquisitionsCFStmt \\
Capital Expenditures & WS.CapitalExpendCFstd \\
Cash and Cash Equivalents & WS.CashAndEquivGeneric \\
Cash Flow & WS.CashFlow \\
Dividend & WS.CommonDividendsCash \\
EBIT & WS.EarningsBeforeInterestAndTaxes \\
EBITDA & WS.EarningsBeforeIntTaxesAndDepr \\
Income Tax & WS.IncomeTaxes \\
Industry code & WS.IndustryGroup \\
Interest expenses & TF.InterestExpenseonDebt \\
Long Term Debt Issuance & WS.LTDebtIssuanceCFStmt \\
Long Term Debt Reduction & WS.LTDebtReductionCFStmt \\
Market capitalization & WS.YrEndMarketCap \\
Working Capital & WS.WorkingCapBalSht \\
Property, Plant \& Equipment & WS.TotalPropPlantEquipNet \\
Purchase of Common \& Preferred Stock & WS.PurchOfComAndPfdStkCFStmt \\
R\&D & WS.ResearchAndDevelopmentExpense \\
Return index & DS.ReturnIndex \\
Return on Assets & WS.ReturnOnAssets \\
Sale of Common \& Preferred Stock & WS.SaleOfComAndPfdStkCFStmt \\
Sales Growth 3Yr & WS.Sales3YrGrowth \\
Share Price & DS.PriceClose \\
Total Assets & WS.TotalAssets \\
Total Debt & WS.TotalDebt \\
Total shares outstanding & DS.CommonSharesOutstanding \\
\hline &
\end{tabular}


Appendix B Cash-to-assets per country, 2000-2004

Table B.1 Summary statistics of cash-to-assets by country, 2000-2004.

The cash-to-assets ratio is defined as Cash and Cash Equivalents divided by Net Assets, where Net Assets is Total Assets minus Cash and Cash Equivalents. The cash-to-assets ratio is winsorized at the mean plus and minus three times the standard deviation. The rightmost column in the table shows the number of observations.

\begin{tabular}{lcccccr}
\hline Country & Mean & $\begin{array}{c}25 \text { th } \\
\text { Percentile }\end{array}$ & Median & $\begin{array}{c}75 \text { th } \\
\text { Percentile }\end{array}$ & Std. Dev. & N \\
\hline Austria & 0.030 & 0.005 & 0.027 & 0.041 & 0.032 & 15 \\
Belgium & 0.118 & 0.043 & 0.088 & 0.174 & 0.088 & 30 \\
Switzerland & 0.244 & 0.101 & 0.225 & 0.357 & 0.174 & 90 \\
Denmark & 0.126 & 0.062 & 0.113 & 0.158 & 0.088 & 24 \\
Finland & 0.172 & 0.018 & 0.028 & 0.159 & 0.291 & 20 \\
France & 0.167 & 0.055 & 0.106 & 0.186 & 0.184 & 234 \\
Germany & 0.126 & 0.035 & 0.075 & 0.162 & 0.143 & 165 \\
Greece & 0.172 & 0.010 & 0.045 & 0.149 & 0.274 & 25 \\
Ireland & 0.455 & 0.160 & 0.322 & 0.830 & 0.319 & 15 \\
Itlay & 0.094 & 0.043 & 0.083 & 0.125 & 0.089 & 73 \\
Luxembourg & 0.066 & 0.047 & 0.056 & 0.083 & 0.031 & 15 \\
Netherlands & 0.164 & 0.053 & 0.099 & 0.219 & 0.158 & 80 \\
Norway & 0.169 & 0.073 & 0.097 & 0.256 & 0.153 & 20 \\
Portugal & 0.081 & 0.012 & 0.027 & 0.184 & 0.096 & 10 \\
Spain & 0.114 & 0.024 & 0.079 & 0.137 & 0.123 & 80 \\
Sweden & 0.168 & 0.044 & 0.082 & 0.156 & 0.230 & 70 \\
United Kingdom & 0.133 & 0.037 & 0.070 & 0.156 & 0.162 & 374 \\
All & 0.149 & 0.041 & 0.087 & 0.177 & 0.173 & 1340 \\
\hline
\end{tabular}


Appendix C Cash-to-assets per industry, 2000-2004

Table C.1 Summary statistics of cash-to-assets by industry, 2000-2004.

The cash-to-assets ratio is defined as Cash and Cash Equivalents divided by Net Assets, where Net Assets is Total Assets minus Cash and Cash Equivalents. The cash-to-assets ratio is winsorized at the mean plus and minus three times the standard deviation. The rightmost column in the table shows the number of observations.

\begin{tabular}{lcccccr}
\hline Industry & Mean & $\begin{array}{c}25 \text { th } \\
\text { Percentile }\end{array}$ & Median & Percentile & Std. Dev. & N \\
\hline Aerospace & 0.210 & 0.127 & 0.179 & 0.245 & 0.109 & 15 \\
Apparel & 0.100 & 0.028 & 0.109 & 0.156 & 0.062 & 10 \\
Automotive & 0.144 & 0.071 & 0.107 & 0.137 & 0.128 & 50 \\
Beverages & 0.063 & 0.026 & 0.052 & 0.088 & 0.046 & 35 \\
Chemicals & 0.100 & 0.033 & 0.065 & 0.151 & 0.088 & 99 \\
Construction & 0.129 & 0.068 & 0.118 & 0.151 & 0.089 & 80 \\
Diversified & 0.134 & 0.046 & 0.084 & 0.161 & 0.134 & 80 \\
Drugs, cosmetics and health care & 0.262 & 0.115 & 0.253 & 0.367 & 0.197 & 85 \\
Electrical & 0.157 & 0.083 & 0.134 & 0.210 & 0.097 & 22 \\
Electronics & 0.314 & 0.107 & 0.217 & 0.399 & 0.273 & 80 \\
Food & 0.170 & 0.062 & 0.087 & 0.224 & 0.164 & 40 \\
Machinery and equipment & 0.190 & 0.042 & 0.068 & 0.349 & 0.200 & 35 \\
Metal producers & 0.089 & 0.052 & 0.070 & 0.112 & 0.073 & 25 \\
Metal product manufacturers & 0.107 & 0.045 & 0.060 & 0.160 & 0.086 & 20 \\
Oil, gas, coal and related services & 0.053 & 0.032 & 0.041 & 0.068 & 0.036 & 44 \\
Paper & 0.023 & 0.017 & 0.024 & 0.027 & 0.008 & 15 \\
Printing and publishing & 0.154 & 0.024 & 0.053 & 0.159 & 0.231 & 48 \\
Recreation & 0.074 & 0.022 & 0.049 & 0.101 & 0.084 & 40 \\
Retialers & 0.143 & 0.052 & 0.087 & 0.146 & 0.175 & 89 \\
Textiles & 0.143 & 0.106 & 0.135 & 0.175 & 0.043 & 5 \\
Tobacco & 0.142 & 0.058 & 0.131 & 0.181 & 0.103 & 20 \\
Transportation & 0.232 & 0.074 & 0.108 & 0.251 & 0.250 & 39 \\
Utilities & 0.090 & 0.019 & 0.050 & 0.107 & 0.125 & 203 \\
Miscellaneous & 0.181 & 0.048 & 0.118 & 0.203 & 0.208 & 161 \\
All & 0.149 & 0.041 & 0.087 & 0.177 & 0.173 & 1340 \\
\hline
\end{tabular}




\section{References}

Bauer, R., N. Guenster and R. Otten (2004), Empirical evidence on corporate governance in Europe: The effect on stock returns, firm value and performance, Journal of Asset Management 5, 91-104.

Bebchuk, L., Cohen, A., and A. Ferrell (2005), What matters in corporate governance, working paper, Harvard Law School.

Brown, L.D. and M.L. Caylor (2006), Corporate governance and firm performance, Journal of Accouting and Public Policy 25, 409-434.

Core, J., Holthausen, R. and D. Larcker, (1999), Corporate governance, chief executive officer compensation and firm performance, Journal of Financial Economics 51, 655-687.

Core, J., Guay, W. and T. Rusticus (2006), Does weak governance cause weak stock returns? An examination of firm operating performance and analysts expectations, Journal of Finance 61, 655-697.

Cremers, K. and V. Nair (2005), Governance mechanisms and equity prices, Journal of Finance 60, 2859-2894.

Deminor Rating (2004), Corporate Governance Research \& Rating Service, version 2004-1.

Dittmar, A., J. Mahrt-Smith and H. Servaes (2003), International corporate governance and corporate cash holdings, Journal of Financial and Quantitative Analysis 38, 111-133.

Dittmar, A. and J. Mahrt-Smith (2007), Corporate governance and the value of cash Holdings, Journal of Financial Economics 83, 599-634.

Faleye, O. (2004), Cash and corporate control, Journal of Finance 59, 2041-2060.

Fama, E.F and K.R. French (1998), Taxes, financing decisions, and firm value, Journal of Finance 53, 819-843.

Faulkender, M.W. and R. Wang (2006), Corporate financial policy and the value of cash, Journal of Finance 61, 1957-1990.

Ferreira, M.A. and A.S. Vilela (2004), Why do firms hold cash? Evidence from EMU countries, European Financial Management 10, 295-319.

Foley, C.F., J.C. Hartzell, S. Titman and G. Twite (2007), Why do firms hold so much cash? A tax-based explanation, Journal of Financial Economics 86, 579-607.

Gompers, P., J. Ishii and A. Metrick (2003), Corporate governance and equity prices, Quarterly Journal of Economics 118, 107-155. 
Harford, J. (1999), Corporate cash reserves and acquisitions, Journal of Finance 54, 1969-1997.

Harford, J., S. Mansi, and W. Maxwell (2008), Corporate governance and firm cash holdings in the US, Journal of Financial Economics 87, 535-555.

Jensen, M.C. (1986), Agency costs of free cash flow, corporate finance and takeovers, American Economic Review 76, 323-329.

Jensen, M.C. and W. Meckling (1976), The Theory of the firm: Managerial Behavior, Agency Costs and the Ownership Structure, Journal of Financial Economics 3, 305-360.

Kim, C., D. Mauer and A. Sherman (1998), The determinants of corporate liquidity: theory and evidence, Journal of Financial and Quantitative Analysis 33, 335-359.

LaPorta, R.A., F. Lopez-de-Silanes and A. Shleifer (1998), Law and finance, Journal of Political Economy 106, 1113-1155.

Myers, S.C. and R.G. Rajan (1998), The paradox of liquidity, Quarterly Journal of Economics 108, 733-771.

Nesbitt, S. (1994), Long-term rewards from shareholder activism: A Study of the "CalPERS effect", Journal of Applied Corporate Finance, Winter, 75-80.

Nesbitt, S. (1995), The "CalPERS effect": A corporate governance update, Journal of Applied Corporate Finance, July, 200-209.

Opler, T., L. Pinkowitz, R. Stulz and R. Williamson (1999), The determinants and implications of cash holdings, Journal of Financial Economics 52, 3-46.

Ozkan, A. and N. Ozkan (2004), Corporate cash holdings: an empirical investigation of UK companies, Journal of Banking and Finance 28, 2103-2134.

Pinkowitz, L. (2000), The market for corporate control and corporate cash holdings, working paper, Georgetown University.

Pinkowitz, L., R. Stulz and R. Williamson (2004), Why do firms in countries with poor protection of investor rights hold more cash, NBER working paper No. 10188.

Pinkowitz, L., R. Stulz and R. Williamson (2006), Does the contribution of corporate cash holdings and dividends to firm value depend on governance? A cross-country analysis, Journal of Finance 61, 2725-2751.

Pinkowitz, L. and R. Williamson (2005), What is a dollar worth? The market value of cash holdings?, working paper, Georgetown University.

Yermack, D. (1996), Higher market valuation of companies with a small board of directors, Journal of Financial Economics 40, 185-211. 
Table 1. Corporate governance scores per year, 2000-2004

\begin{tabular}{|c|c|c|c|c|c|c|c|}
\hline \multirow[t]{2}{*}{ Year } & \multicolumn{2}{|c|}{ Governance total } & \multirow{2}{*}{$\begin{array}{c}\text { Shareholder } \\
\text { rights }\end{array}$} & \multirow{2}{*}{$\begin{array}{l}\text { Takeover } \\
\text { defences }\end{array}$} & \multirow[t]{2}{*}{ Disclosure } & \multirow[t]{2}{*}{ Board } & \multirow{2}{*}{$\mathrm{N}$} \\
\hline & Mean & $\begin{array}{l}\text { Standard } \\
\text { deviation }\end{array}$ & & & & & \\
\hline 2000 & 19.02 & 6.38 & 6.01 & 3.82 & 4.88 & 4.35 & 150 \\
\hline 2001 & 20.69 & 6.58 & 6.26 & 4.14 & 5.65 & 4.64 & 166 \\
\hline 2002 & 20.98 & 6.27 & 6.36 & 3.86 & 6.03 & 4.74 & 191 \\
\hline 2003 & 22.48 & 6.19 & 6.58 & 3.89 & 6.73 & 5.28 & 194 \\
\hline 2004 & 23.84 & 5.65 & 6.89 & 4.05 & 7.06 & 5.83 & 204 \\
\hline All & 21.57 & 6.39 & 6.45 & 3.95 & 6.15 & 5.02 & 905 \\
\hline
\end{tabular}

Note: The table presents average Deminor corporate governance scores per year for Shareholder rights, Takeover defences, Disclosure and Board. For the total governance score the standard deviation is shown as well. The rightmost column shows the number of observations. 
Table 2. Corporate governance scores by country, 2000-2004

\begin{tabular}{|c|c|c|c|c|c|c|c|}
\hline \multirow[t]{2}{*}{ Country } & \multicolumn{2}{|c|}{ Governance total } & \multirow{2}{*}{$\begin{array}{c}\text { Shareholder } \\
\text { rights }\end{array}$} & \multirow{2}{*}{$\begin{array}{l}\text { Takeover } \\
\text { defences }\end{array}$} & \multirow[t]{2}{*}{ Disclosure } & \multirow[t]{2}{*}{ Board } & \multirow{2}{*}{$\mathrm{N}$} \\
\hline & Mean & $\begin{array}{l}\text { Standard } \\
\text { deviation }\end{array}$ & & & & & \\
\hline Austria & 17.61 & 2.01 & 7.36 & 0.81 & 5.83 & 3.61 & 3 \\
\hline Belgium & 17.45 & 3.17 & 6.51 & 1.64 & 4.67 & 4.63 & 21 \\
\hline Switzerland & 16.61 & 6.05 & 5.58 & 2.28 & 4.78 & 3.96 & 53 \\
\hline Denmark & 15.60 & 3.90 & 6.05 & 1.35 & 4.86 & 3.35 & 17 \\
\hline Finland & 23.55 & 3.97 & 6.98 & 5.64 & 6.12 & 4.80 & 18 \\
\hline France & 20.79 & 4.59 & 6.40 & 3.42 & 5.83 & 5.14 & 163 \\
\hline Germany & 18.92 & 3.97 & 7.18 & 2.88 & 5.48 & 3.38 & 113 \\
\hline Greece & 16.80 & 3.06 & 6.97 & 1.29 & 4.84 & 3.71 & 7 \\
\hline Ireland & 28.09 & 2.11 & 6.65 & 8.09 & 6.90 & 6.45 & 11 \\
\hline Italy & 19.55 & 3.00 & 6.18 & 1.42 & 6.97 & 4.98 & 40 \\
\hline Luxembourg & 12.08 & 5.35 & 4.01 & 0.50 & 3.96 & 3.61 & 2 \\
\hline Netherlands & 17.23 & 5.47 & 4.89 & 1.97 & 5.99 & 4.39 & 71 \\
\hline Norway & 18.95 & 4.06 & 7.59 & 2.91 & 4.66 & 3.79 & 16 \\
\hline Portugal & 12.13 & 3.23 & 4.13 & 0.25 & 4.68 & 3.07 & 8 \\
\hline Spain & 16.60 & 3.38 & 5.58 & 1.08 & 5.26 & 4.68 & 43 \\
\hline Sweden & 19.27 & 4.95 & 5.93 & 4.09 & 5.13 & 4.12 & 55 \\
\hline United Kingdom & 27.93 & 4.77 & 7.02 & 6.79 & 7.56 & 6.56 & 264 \\
\hline All & 21.57 & 6.39 & 6.45 & 3.95 & 6.15 & 5.02 & 905 \\
\hline
\end{tabular}

Note: The table presents average Deminor corporate governance scores by country for Shareholder rights, Takeover defences, Disclosure and Board. For the total governance score the standard deviation is shown as well. The rightmost column shows the number of observations. 
Table 3. Corporate governance scores by industry, 2000-2004

\begin{tabular}{|c|c|c|c|c|c|c|c|}
\hline \multirow[t]{2}{*}{ Industry } & \multicolumn{2}{|c|}{ Governance total } & \multirow{2}{*}{$\begin{array}{c}\text { Shareholder } \\
\text { rights }\end{array}$} & \multirow{2}{*}{$\begin{array}{l}\text { Takeover } \\
\text { defences } \\
\end{array}$} & \multirow[t]{2}{*}{ Disclosure } & \multirow[t]{2}{*}{ Board } & \multirow{2}{*}{$\mathrm{N}$} \\
\hline & Mean & $\begin{array}{l}\text { Standard } \\
\text { deviation }\end{array}$ & & & & & \\
\hline Aerospace & 18.73 & 2.06 & 5.22 & 0.25 & 7.32 & 5.93 & 12 \\
\hline Apparel & 21.71 & 5.85 & 7.25 & 5.15 & 5.65 & 3.67 & 3 \\
\hline Automotive & 19.59 & 4.42 & 6.30 & 3.73 & 5.58 & 3.98 & 43 \\
\hline Beverages & 23.30 & 6.40 & 7.12 & 3.89 & 6.54 & 5.75 & 23 \\
\hline Chemicals & 21.02 & 6.59 & 6.46 & 4.12 & 5.74 & 4.70 & 76 \\
\hline Construction & 24.98 & 5.13 & 6.75 & 6.05 & 6.51 & 5.67 & 32 \\
\hline Diversified & 20.45 & 5.09 & 6.52 & 3.67 & 5.59 & 4.67 & 59 \\
\hline Drugs, cosmetics and health care & 20.53 & 6.72 & 6.62 & 3.22 & 5.99 & 4.74 & 67 \\
\hline Electrical & 21.45 & 4.15 & 6.36 & 3.91 & 6.02 & 5.16 & 18 \\
\hline Electronics & 21.75 & 5.78 & 6.39 & 4.20 & 6.23 & 4.93 & 60 \\
\hline Food & 22.58 & 7.06 & 6.06 & 4.46 & 6.77 & 5.38 & 35 \\
\hline Machinery and equipment & 21.39 & 5.32 & 6.46 & 5.96 & 5.14 & 3.83 & 27 \\
\hline Metal producers & 25.57 & 5.74 & 6.59 & 4.60 & 7.60 & 6.77 & 15 \\
\hline Metal product manufacturers & 25.55 & 7.52 & 6.84 & 6.69 & 6.50 & 5.52 & 10 \\
\hline Oil, gas, coal and related services & 22.69 & 6.45 & 6.35 & 3.56 & 6.92 & 5.86 & 30 \\
\hline Paper & 20.57 & 4.71 & 6.14 & 4.38 & 5.67 & 4.37 & 15 \\
\hline Printing and publishing & 22.86 & 7.30 & 5.82 & 4.99 & 6.60 & 5.45 & 36 \\
\hline Recreation & 21.73 & 5.32 & 7.12 & 3.13 & 6.34 & 5.15 & 18 \\
\hline Retailers & 23.19 & 6.86 & 6.88 & 4.73 & 6.20 & 5.37 & 68 \\
\hline Textiles & 22.21 & 0.30 & 8.11 & 0.50 & 7.03 & 6.57 & 2 \\
\hline Tobacco & 26.30 & 6.19 & 6.81 & 6.40 & 6.87 & 6.21 & 19 \\
\hline Transportation & 19.53 & 5.56 & 6.19 & 2.09 & 6.44 & 4.81 & 22 \\
\hline Utilities & 19.53 & 6.74 & 6.17 & 2.59 & 6.01 & 4.76 & 149 \\
\hline Miscellaneous & 22.91 & 6.69 & 6.70 & 4.70 & 6.27 & 5.24 & 66 \\
\hline All & 21.57 & 6.39 & 6.45 & 3.95 & 6.15 & 5.02 & 905 \\
\hline
\end{tabular}

Note: The table presents average Deminor corporate governance scores by industry for Shareholder rights, Takeover defences, Disclosure and Board. For the total governance score the standard deviation is shown as well. The rightmost column shows the number of observations. 
Table 4. Summary statistics cash-to-assets ratio by country, 1990-2005

The cash-to-assets ratio is defined as Cash and Cash Equivalents divided by Net Assets, where Net Assets is Total Assets minus Cash and Cash Equivalents. The cash-to-assets ratio is winsorized at the mean plus and minus three times the standard deviation.

\begin{tabular}{lcccccr}
\hline Country & Mean & $\begin{array}{c}\text { 25th } \\
\text { Percentile }\end{array}$ & Median & $\begin{array}{c}75 \text { th } \\
\text { Percentile }\end{array}$ & Std. Dev. & N \\
\hline Austria & 0.038 & 0.007 & 0.027 & 0.051 & 0.038 & 41 \\
Belgium & 0.109 & 0.035 & 0.071 & 0.173 & 0.101 & 93 \\
Switzerland & 0.263 & 0.091 & 0.225 & 0.376 & 0.208 & 235 \\
Denmark & 0.176 & 0.086 & 0.141 & 0.240 & 0.131 & 54 \\
Finland & 0.137 & 0.027 & 0.044 & 0.152 & 0.209 & 61 \\
France & 0.152 & 0.062 & 0.104 & 0.179 & 0.157 & 691 \\
Germany & 0.150 & 0.048 & 0.101 & 0.204 & 0.153 & 466 \\
Greece & 0.156 & 0.012 & 0.057 & 0.150 & 0.238 & 46 \\
Ireland & 0.458 & 0.190 & 0.405 & 0.738 & 0.265 & 37 \\
Italy & 0.123 & 0.042 & 0.093 & 0.158 & 0.116 & 212 \\
Luxembourg & 0.119 & 0.053 & 0.080 & 0.125 & 0.120 & 32 \\
Netherlands & 0.147 & 0.051 & 0.090 & 0.194 & 0.151 & 238 \\
Norway & 0.178 & 0.064 & 0.087 & 0.342 & 0.176 & 56 \\
Portugal & 0.060 & 0.003 & 0.013 & 0.060 & 0.096 & 24 \\
Spain & 0.095 & 0.017 & 0.060 & 0.137 & 0.104 & 239 \\
Sweden & 0.177 & 0.050 & 0.108 & 0.197 & 0.209 & 204 \\
United Kingdom & 0.157 & 0.043 & 0.093 & 0.194 & 0.178 & 1102 \\
All & 0.156 & 0.046 & 0.099 & 0.197 & 0.172 & 3831 \\
\hline
\end{tabular}


Table 5. Summary statistics cash-to-assets ratio by industry, 1990-2005

The cash-to-assets ratio is defined as Cash and Cash Equivalents divided by Net Assets, where Net Assets is Total Assets minus Cash and Cash Equivalents. The cash-to-assets ratio is winsorized at the mean plus and minus three times the standard deviation.

\begin{tabular}{lcccccr}
\hline Industry & Mean & $\begin{array}{c}25 \text { th } \\
\text { Percentile }\end{array}$ & Median & Percentile & Std. Dev. & N \\
& 0.223 & 0.170 & 0.200 & 0.253 & 0.083 & 40 \\
\hline Aerospace & 0.154 & 0.029 & 0.119 & 0.255 & 0.134 & 31 \\
Apparel & 0.167 & 0.086 & 0.137 & 0.200 & 0.126 & 149 \\
Automotive & 0.093 & 0.038 & 0.071 & 0.127 & 0.077 & 110 \\
Beverages & 0.091 & 0.038 & 0.065 & 0.129 & 0.073 & 274 \\
Chemicals & 0.146 & 0.067 & 0.115 & 0.171 & 0.132 & 235 \\
Construction & 0.155 & 0.063 & 0.106 & 0.175 & 0.143 & 247 \\
Diversified & 0.283 & 0.121 & 0.244 & 0.389 & 0.215 & 234 \\
Drugs, cosmetics and health care & 0.128 & 0.082 & 0.108 & 0.157 & 0.073 & 53 \\
Electrical & 0.283 & 0.127 & 0.203 & 0.338 & 0.234 & 241 \\
Electronics & 0.188 & 0.072 & 0.100 & 0.258 & 0.179 & 118 \\
Food & 0.193 & 0.050 & 0.183 & 0.271 & 0.165 & 99 \\
Machinery and equipment & 0.129 & 0.067 & 0.107 & 0.155 & 0.102 & 64 \\
Metal producers & 0.110 & 0.050 & 0.066 & 0.141 & 0.100 & 60 \\
Metal product manufacturers & 0.066 & 0.031 & 0.052 & 0.084 & 0.052 & 133 \\
Oil, gas, coal and related services & 0.034 & 0.021 & 0.030 & 0.042 & 0.017 & 45 \\
Paper & 0.128 & 0.026 & 0.064 & 0.150 & 0.173 & 148 \\
Printing and publishing & 0.109 & 0.038 & 0.077 & 0.130 & 0.105 & 119 \\
Recreation & 0.158 & 0.053 & 0.086 & 0.163 & 0.193 & 280 \\
Retialers & 0.153 & 0.113 & 0.135 & 0.196 & 0.048 & 7 \\
Textiles & 0.122 & 0.045 & 0.097 & 0.181 & 0.094 & 52 \\
Tobacco & 0.209 & 0.075 & 0.132 & 0.243 & 0.204 & 97 \\
Transportation & 0.082 & 0.014 & 0.039 & 0.101 & 0.116 & 553 \\
Utilities & 0.214 & 0.059 & 0.154 & 0.253 & 0.221 & 442 \\
Miscellaneous & 0.156 & 0.046 & 0.099 & 0.197 & 0.172 & 3831 \\
All & & & & & &
\end{tabular}


Table 6. Normal cash model

This table shows the regression results of the cash models. In all variables Assets are net of Cash. The dependent variable is the ratio Cash / assets. The independent variables include: Size (natural logarithm of the firm real assets), Market-to-Book ((Market capitalization + Total Debt) / Assets), Cash Flow / Assets, NWC / Assets (Net Working Capital / Assets), Sigma (Industry Cash Flow volatility over past 6 years), R\&D / Assets (Research and Development, set to zero if missing), Leverage (Total Debt / Assets), Capex / Assets (Capital Expenditures / Assets), Dividend Dummy (set to 1 if the firm pays dividend, zero otherwise), Governance total (sum of Shareholder rights, Takeover defences, Disclosure and Board), Shareholder rights, Takeover defences, Disclosure and Board. Regressions are made with firm fixed and year fixed effects. OLS regression is used with White's heteroskedasticity consistent standard errors. Standard errors are presented between parentheses. *, **, and *** denote statistical significance at the $0.10,0.05$, and 0.01 level, respectively.

\begin{tabular}{|c|c|c|c|c|c|c|}
\hline Variables & $\begin{array}{c}\text { Predicted } \\
\text { sign }\end{array}$ & {$[1]$} & [2] & {$[3]$} & [4] & {$[5]$} \\
\hline Size & $?$ & $\begin{array}{c}0.006 \\
(0.007)\end{array}$ & $\begin{array}{c}0.002 \\
(0.007)\end{array}$ & $\begin{array}{c}0.002 \\
(0.008)\end{array}$ & $\begin{array}{c}-0.010 \\
(0.015)\end{array}$ & $\begin{array}{l}-0.011 \\
(0.016)\end{array}$ \\
\hline Market to Book & + & $\begin{array}{c}0.018 * * * \\
(0.004)\end{array}$ & $\begin{array}{c}0.018 * * * \\
(0.004)\end{array}$ & $\begin{array}{c}0.021 * * * \\
(0.004)\end{array}$ & $\begin{array}{c}0.011 \\
(0.010)\end{array}$ & $\begin{array}{c}0.011 \\
(0.010)\end{array}$ \\
\hline Cash Flow / Assets & + & $\begin{array}{c}0.379 * * * \\
(0.095)\end{array}$ & $\begin{array}{c}0.445 * * * \\
(0.104)\end{array}$ & $\begin{array}{c}0.482 * * * \\
(0.104)\end{array}$ & $\begin{array}{c}0.271^{* * * *} \\
(0.094)\end{array}$ & $\begin{array}{c}0.281 * * * \\
(0.099)\end{array}$ \\
\hline NWC / Assets & - & $\begin{array}{c}-0.233 * * * \\
(0.030)\end{array}$ & $\begin{array}{c}-0.193 * * * \\
(0.032)\end{array}$ & $\begin{array}{c}-0.191 * * * \\
(0.031)\end{array}$ & $\begin{array}{c}-0.271 * * * \\
(0.062)\end{array}$ & $\begin{array}{c}-0.268 * * * \\
(0.059)\end{array}$ \\
\hline Sigma & + & $\begin{array}{c}0.625 * * * \\
(0.074)\end{array}$ & $\begin{array}{c}0.602 * * * \\
(0.077)\end{array}$ & $\begin{array}{c}0.673 * * * \\
(0.071)\end{array}$ & $\begin{array}{c}0.440^{* * * *} \\
(0.150)\end{array}$ & $\begin{array}{c}0.445^{* * *} \\
(0.156)\end{array}$ \\
\hline R\&D / Assets & + & $\begin{array}{c}1.144 * * * \\
(0.143)\end{array}$ & $\begin{array}{c}1.114 * * * \\
(0.139)\end{array}$ & & $\begin{array}{c}2.237 * * * \\
(0.356)\end{array}$ & $\begin{array}{c}2.243 * * * \\
(0.373)\end{array}$ \\
\hline Leverage & $?$ & & $\begin{array}{c}0.115 * * * \\
(0.020)\end{array}$ & $\begin{array}{c}0.122 * * * \\
(0.016)\end{array}$ & & \\
\hline Capex / Assets & + & & $\begin{array}{l}-0.037 \\
(0.061)\end{array}$ & & & \\
\hline Dividend Dummy & - & & $\begin{array}{l}-0.008 \\
(0.006)\end{array}$ & $\begin{array}{l}-0.010 \\
(0.007)\end{array}$ & & \\
\hline Governance total & & & & & $\begin{array}{c}0.002 * * \\
(0.001)\end{array}$ & \\
\hline Shareholder rights & & & & & & $\begin{array}{c}-0.002 \\
(0.004)\end{array}$ \\
\hline Takeover defences & & & & & & $\begin{array}{c}0.005 * * * \\
(0.001)\end{array}$ \\
\hline Disclosure & & & & & & $\begin{array}{l}-0.003 \\
(0.003)\end{array}$ \\
\hline Board & & & & & & $\begin{array}{l}-0.001 \\
(0.006)\end{array}$ \\
\hline Constant & & $\begin{array}{l}-0.031 \\
(0.072)\end{array}$ & $\begin{array}{l}-0.024 \\
(0.068)\end{array}$ & $\begin{array}{l}-0.009 \\
(0.074)\end{array}$ & $\begin{array}{c}0.049 \\
(0.150)\end{array}$ & $\begin{array}{c}0.128 \\
(0.176)\end{array}$ \\
\hline Adjusted partial $R^{2}$ & & 0.200 & 0.208 & 0.185 & 0.254 & 0.255 \\
\hline Sample Size & & 3154 & 3142 & 3154 & 842 & 842 \\
\hline
\end{tabular}


Table 7. Value models

This table shows the regression results for the value regressions. All models are estimated with firm and year fixed effects. In all variables Assets are net of Cash. The dependent variable in all models is the ratio of firm's market value to assets. The independent variables include the following variables over assets: Earnings, R\&D, Dividend, Interest, Assets, Market Value and Excess Cash. Excess cash is computed as the residual from model [1] in Table 6. In model [2]-[5] X is equal to, Shareholder rights, Takeover defences, Disclosure and Board respectively. In model [1] $X$ is equal to the sum of Shareholder rights, Takeover defences, Disclosure and Board. $\Delta \mathrm{L} Y$ indicates a change in $\mathrm{Y}$ from time $\mathrm{t}-1$ to $\mathrm{t}$. $\Delta \mathrm{Y}$ indicates a change in $\mathrm{Y}$ from time $\mathrm{t}$ to $\mathrm{t}+1$. All models use only firms with positive excess cash. OLS regression is used with White's heteroskedasticity consistent standard errors. Standard errors are presented between parentheses. $*, * *$, and $* * *$ denote statistical significance at the $0.10,0.05$, and 0.01 level, respectively.

\begin{tabular}{|c|c|c|c|c|c|}
\hline Variables & {$[1]$} & {$[2]$} & {$[3]$} & [4] & {$[5]$} \\
\hline Earnings / Assets & $\begin{array}{c}2.507 * * * \\
(0.616)\end{array}$ & $\begin{array}{c}1.979 * * * \\
(0.709)\end{array}$ & $\begin{array}{c}2.788 * * * \\
(0.757)\end{array}$ & $\begin{array}{c}2.013 * * * \\
(0.614)\end{array}$ & $\begin{array}{c}1.984 * * * \\
(0.716)\end{array}$ \\
\hline$\Delta$ L Earnings / Assets & $\begin{array}{c}-0.256 \\
(0.246)\end{array}$ & $\begin{array}{c}0.074 \\
(0.173)\end{array}$ & $\begin{array}{l}-0.376 \\
(0.285)\end{array}$ & $\begin{array}{c}-0.036 \\
(0.178)\end{array}$ & $\begin{array}{c}0.066 \\
(0.198)\end{array}$ \\
\hline$\Delta$ Earnings / Assets & $\begin{array}{c}1.062 \\
(0.652)\end{array}$ & $\begin{array}{c}1.008 \\
(0.807)\end{array}$ & $\begin{array}{l}1.142 * \\
(0.645)\end{array}$ & $\begin{array}{c}1.017 \\
(0.673)\end{array}$ & $\begin{array}{c}1.024 \\
(0.792)\end{array}$ \\
\hline $\mathrm{R} \& \mathrm{D} /$ Assets & $\begin{array}{l}7.525^{* *} \\
(3.273)\end{array}$ & $\begin{array}{l}5.265^{* *} \\
(2.602)\end{array}$ & $\begin{array}{c}10.059 * * * \\
(3.377)\end{array}$ & $\begin{array}{c}5.026 * * \\
(2.118)\end{array}$ & $\begin{array}{c}6.092 * \\
(3.157)\end{array}$ \\
\hline$\Delta \mathrm{L} R \& \mathrm{D} /$ Assets & $\begin{array}{c}1.744 \\
(3.485)\end{array}$ & $\begin{array}{c}2.951 \\
(3.405)\end{array}$ & $\begin{array}{c}1.554 \\
(2.848)\end{array}$ & $\begin{array}{c}1.720 \\
(3.812)\end{array}$ & $\begin{array}{c}3.025 \\
(3.277)\end{array}$ \\
\hline$\Delta \mathrm{R} \& \mathrm{D} /$ Assets & $\begin{array}{c}8.127 * * * \\
(2.479)\end{array}$ & $\begin{array}{c}8.195 * * * \\
(2.820)\end{array}$ & $\begin{array}{c}8.786 * * * \\
(2.153)\end{array}$ & $\begin{array}{c}8.271 * * * \\
(2.274)\end{array}$ & $\begin{array}{c}8.553 * * * \\
(2.826)\end{array}$ \\
\hline Dividend / Assets & $\begin{array}{c}1.541 * * * \\
(0.324)\end{array}$ & $\begin{array}{c}1.824 * * * \\
(0.277)\end{array}$ & $\begin{array}{c}1.394 * * * \\
(0.287)\end{array}$ & $\begin{array}{c}1.588^{* * *} \\
(0.322)\end{array}$ & $\begin{array}{c}1.852 * * * \\
(0.317)\end{array}$ \\
\hline$\Delta$ L Dividend / Assets & $\begin{array}{l}2.624 * \\
(1.545)\end{array}$ & $\begin{array}{c}1.551 \\
(1.229)\end{array}$ & $\begin{array}{c}3.283 * * * \\
(1.052)\end{array}$ & $\begin{array}{c}2.585 \\
(1.696)\end{array}$ & $\begin{array}{c}1.427 \\
(1.485)\end{array}$ \\
\hline$\Delta$ Dividend / Assets & $\begin{array}{c}-0.009 \\
(0.283)\end{array}$ & $\begin{array}{l}-0.072 \\
(0.315)\end{array}$ & $\begin{array}{c}0.001 \\
(0.292)\end{array}$ & $\begin{array}{c}0.042 \\
(0.208)\end{array}$ & $\begin{array}{c}-0.097 \\
(0.273)\end{array}$ \\
\hline Interest / Assets & $\begin{array}{l}-11.462 \\
(12.375)\end{array}$ & $\begin{array}{l}-15.611 \\
(12.643)\end{array}$ & $\begin{array}{l}-9.618 \\
(7.936)\end{array}$ & $\begin{array}{l}-10.183 \\
(12.846)\end{array}$ & $\begin{array}{l}-17.429 \\
(11.633)\end{array}$ \\
\hline$\Delta$ L Interest / Assets & $\begin{array}{c}-0.450 \\
(1.881)\end{array}$ & $\begin{array}{l}-1.650 \\
(2.135)\end{array}$ & $\begin{array}{l}-0.508 \\
(3.535)\end{array}$ & $\begin{array}{c}-1.440 \\
(2.213)\end{array}$ & $\begin{array}{l}-1.389 \\
(2.034)\end{array}$ \\
\hline$\Delta$ Interest / Assets & $\begin{array}{l}-15.169 \\
(13.614)\end{array}$ & $\begin{array}{l}-18.300 \\
(12.733)\end{array}$ & $\begin{array}{c}-14.273 \\
(10.122)\end{array}$ & $\begin{array}{l}-14.094 \\
(12.737)\end{array}$ & $\begin{array}{l}-19.046 \\
(12.344)\end{array}$ \\
\hline$\Delta \mathrm{L}$ NA / Assets & $\begin{array}{c}0.250 * \\
(0.149)\end{array}$ & $\begin{array}{l}0.289 * \\
(0.147)\end{array}$ & $\begin{array}{c}0.192 \\
(0.121)\end{array}$ & $\begin{array}{c}0.301 * * * \\
(0.107)\end{array}$ & $\begin{array}{c}0.263 \\
(0.162)\end{array}$ \\
\hline$\Delta \mathrm{NA} /$ Assets & $\begin{array}{l}0.429 * * \\
(0.194)\end{array}$ & $\begin{array}{l}0.458^{* *} \\
(0.178)\end{array}$ & $\begin{array}{c}0.349 * * * \\
(0.130)\end{array}$ & $\begin{array}{l}0.463 * * \\
(0.214)\end{array}$ & $\begin{array}{l}0.466^{* *} \\
(0.207)\end{array}$ \\
\hline$\Delta \mathrm{MV} /$ Assets & $\begin{array}{c}-0.513 * * * \\
(0.084)\end{array}$ & $\begin{array}{c}-0.499 * * * \\
(0.078)\end{array}$ & $\begin{array}{c}-0.496 * * * \\
(0.085)\end{array}$ & $\begin{array}{c}-0.518 * * * \\
(0.070)\end{array}$ & $\begin{array}{c}-0.491 * * * \\
(0.075)\end{array}$ \\
\hline Excess Cash / Assets & $\begin{array}{l}-1.175 \\
(1.214)\end{array}$ & $\begin{array}{c}2.652 \\
(1.750)\end{array}$ & $\begin{array}{c}0.191 \\
(0.633)\end{array}$ & $\begin{array}{c}-0.556 \\
(2.258)\end{array}$ & $\begin{array}{c}2.151 \\
(1.414)\end{array}$ \\
\hline Governance $\mathrm{X}$ & $\begin{array}{l}-0.006 \\
(0.019)\end{array}$ & $\begin{array}{c}0.062 \\
(0.039)\end{array}$ & $\begin{array}{l}-0.078 \\
(0.052)\end{array}$ & $\begin{array}{l}0.066^{*} \\
(0.035)\end{array}$ & $\begin{array}{l}-0.007 \\
(0.031)\end{array}$ \\
\hline Governance X x Excess Cash / Assets & $\begin{array}{c}0.145^{* *} \\
(0.069)\end{array}$ & $\begin{array}{l}-0.152 \\
(0.288)\end{array}$ & $\begin{array}{c}0.508 * * \\
(0.242)\end{array}$ & $\begin{array}{c}0.377 \\
(0.396)\end{array}$ & $\begin{array}{c}-0.080 \\
(0.292)\end{array}$ \\
\hline Constant & $\begin{array}{l}1.270 * * \\
(0.514)\end{array}$ & $\begin{array}{c}0.941 * * * \\
(0.139)\end{array}$ & $\begin{array}{c}1.274 * * * \\
(0.195)\end{array}$ & $\begin{array}{c}0.854 * * * \\
(0.123)\end{array}$ & $\begin{array}{c}1.361 * * * \\
(0.211)\end{array}$ \\
\hline $\begin{array}{l}\text { Adjusted partial } R^{2} \\
\text { Sample Size }\end{array}$ & $\begin{array}{c}0.629 \\
256\end{array}$ & $\begin{array}{c}0.620 \\
256\end{array}$ & $\begin{array}{c}0.649 \\
256\end{array}$ & $\begin{array}{c}0.630 \\
256\end{array}$ & $\begin{array}{c}0.618 \\
256\end{array}$ \\
\hline
\end{tabular}


Table 8. Alternative value models (robustness)

This table shows the regression results for the value regressions. All models are estimated with firm and year fixed effects. In all variables Assets are net of Cash. The dependent variable in all models is the ratio of firm's market value to assets. The independent variables include the following variables over assets: Earnings, R\&D, Dividend, Interest, Assets, Market Value, Normal Cash and Excess Cash. Normal cash is computed with the estimated model [1] in Table 6; Excess cash is computed as the residual from model [1] in Table 6. Gov. TD is the governance score for Takeover defences. $\Delta \mathrm{L} \mathrm{Y}$ indicates a change in $\mathrm{Y}$ from time $\mathrm{t}-1$ to $\mathrm{t} . \Delta \mathrm{Y}$ indicates a change in $\mathrm{Y}$ from time $\mathrm{t}$ to $\mathrm{t}+1$. OLS regression is used with White's heteroskedasticity consistent standard errors. Standard errors are presented between parentheses. *, **, and *** denote statistical significance at the $0.10,0.05$, and 0.01 level, respectively.

\begin{tabular}{|c|c|c|c|c|}
\hline Variables & [1] & [2] & [3] & [4] \\
\hline Earnings / Assets & $\begin{array}{c}2.981 * * * \\
(0.823)\end{array}$ & $\begin{array}{c}2.963 * * * \\
(0.770)\end{array}$ & $\begin{array}{c}2.250 * * * \\
(0.709)\end{array}$ & $\begin{array}{c}2.331 * * * \\
(0.631)\end{array}$ \\
\hline$\Delta$ L Earnings / Assets & $\begin{array}{c}-0.365 \\
(0.286)\end{array}$ & $\begin{array}{l}-0.311 \\
(0.252)\end{array}$ & & \\
\hline$\Delta$ Earnings / Assets & $\begin{array}{l}1.206 * \\
(0.692)\end{array}$ & $\begin{array}{l}1.206^{*} \\
(0.676)\end{array}$ & $\begin{array}{c}0.865 \\
(0.685)\end{array}$ & $\begin{array}{c}0.918 \\
(0.615)\end{array}$ \\
\hline R\&D / Assets & $\begin{array}{c}10.768 * * * \\
(3.195)\end{array}$ & $\begin{array}{c}10.425 * * * \\
(3.504)\end{array}$ & $\begin{array}{c}14.387 * * \\
(6.202)\end{array}$ & $\begin{array}{c}13.635^{* *} \\
(6.145)\end{array}$ \\
\hline$\Delta \mathrm{L} R \& \mathrm{D} /$ Assets & $\begin{array}{c}1.511 \\
(2.798)\end{array}$ & $\begin{array}{c}1.301 \\
(2.979)\end{array}$ & & \\
\hline$\Delta \mathrm{R} \& \mathrm{D} /$ Assets & $\begin{array}{c}8.640 * * * \\
(2.192)\end{array}$ & $\begin{array}{c}8.276^{* * *} \\
(1.999)\end{array}$ & $\begin{array}{c}12.058 * * * \\
(1.829)\end{array}$ & $\begin{array}{c}11.399 * * * \\
(2.087)\end{array}$ \\
\hline Dividend / Assets & $\begin{array}{c}1.368 * * * \\
(0.272)\end{array}$ & $\begin{array}{c}1.348 * * * \\
(0.281)\end{array}$ & $\begin{array}{c}1.650 * * * \\
(0.341)\end{array}$ & $\begin{array}{c}1.604 * * * \\
(0.362)\end{array}$ \\
\hline$\Delta$ L Dividend / Assets & $\begin{array}{c}3.494 * * * \\
(0.844)\end{array}$ & $\begin{array}{c}3.464 * * * \\
(0.958)\end{array}$ & $\begin{array}{c}3.675 * * * \\
(1.334)\end{array}$ & $\begin{array}{l}3.631 * * \\
(1.427)\end{array}$ \\
\hline$\Delta$ Dividend / Assets & $\begin{array}{c}-0.002 \\
(0.285)\end{array}$ & $\begin{array}{c}0.012 \\
(0.277)\end{array}$ & & \\
\hline Interest / Assets & $\begin{array}{c}-9.871 \\
(7.983)\end{array}$ & $\begin{array}{r}-10.180 \\
(8.456)\end{array}$ & & \\
\hline$\Delta \mathrm{L}$ Interest / Assets & $\begin{array}{c}-0.679 \\
(3.582)\end{array}$ & $\begin{array}{c}-0.877 \\
(3.911)\end{array}$ & & \\
\hline$\Delta$ Interest / Assets & $\begin{array}{l}-14.487 \\
(10.094)\end{array}$ & $\begin{array}{c}-14.589 \\
(9.641)\end{array}$ & & \\
\hline$\Delta \mathrm{L} \mathrm{NA} /$ Assets & $\begin{array}{c}0.189 \\
(0.119)\end{array}$ & $\begin{array}{l}0.220 * \\
(0.124)\end{array}$ & $\begin{array}{c}0.232 \\
(0.186)\end{array}$ & $\begin{array}{c}0.261 \\
(0.188)\end{array}$ \\
\hline$\Delta$ NA / Assets & $\begin{array}{c}0.383 * * \\
(0.157)\end{array}$ & $\begin{array}{c}0.395^{* *} \\
(0.159)\end{array}$ & & \\
\hline$\Delta \mathrm{MV} /$ Assets & $\begin{array}{c}-0.501 * * * \\
(0.090)\end{array}$ & $\begin{array}{c}-0.500 * * * \\
(0.093)\end{array}$ & $\begin{array}{c}-0.522 * * * \\
(0.072)\end{array}$ & $\begin{array}{c}-0.517 * * * \\
(0.076)\end{array}$ \\
\hline Normal cash / Assets & $\begin{array}{l}-0.609 \\
(0.993)\end{array}$ & $\begin{array}{c}0.264 \\
(1.610)\end{array}$ & $\begin{array}{c}-0.204 \\
(0.830)\end{array}$ & $\begin{array}{c}1.304 \\
(1.599)\end{array}$ \\
\hline Excess Cash / Assets & $\begin{array}{c}0.217 \\
(0.618)\end{array}$ & $\begin{array}{c}0.086 \\
(0.561)\end{array}$ & $\begin{array}{c}0.161 \\
(0.690)\end{array}$ & $\begin{array}{c}-0.115 \\
(0.692)\end{array}$ \\
\hline Gov. t.d. & $\begin{array}{c}-0.078 \\
(0.051)\end{array}$ & $\begin{array}{l}-0.052 \\
(0.057)\end{array}$ & $\begin{array}{l}-0.080 \\
(0.056)\end{array}$ & $\begin{array}{c}-0.040 \\
(0.057)\end{array}$ \\
\hline Gov. t.d. x Normal Cash / Assets & & $\begin{array}{l}-0.163 \\
(0.161)\end{array}$ & & $\begin{array}{c}-0.259 \\
(0.246)\end{array}$ \\
\hline Gov. t.d. x Excess Cash / Assets & $\begin{array}{c}0.514 * * \\
(0.241)\end{array}$ & $\begin{array}{c}0.531 * * \\
(0.235)\end{array}$ & $\begin{array}{c}0.418 * * \\
(0.173)\end{array}$ & $\begin{array}{c}0.471 * * \\
(0.205)\end{array}$ \\
\hline Constant & $\begin{array}{c}1.332 * * * \\
(0.277)\end{array}$ & $\begin{array}{c}1.210 * * * \\
(0.354)\end{array}$ & $\begin{array}{c}1.119 * * * \\
(0.180)\end{array}$ & $\begin{array}{c}0.892 * * * \\
(0.336)\end{array}$ \\
\hline Adjusted partial $R^{2}$ & 0.648 & 0.655 & 0.629 & 0.640 \\
\hline Sample Size & 256 & 256 & 257 & 257 \\
\hline
\end{tabular}


Table 9. Return models

This table shows the regression results for the return regressions. All models are estimated with firm and year fixed effects. ME is the market value of equity at $\mathrm{t}-1$. The dependent variable in models [1][3] is $\mathrm{ME}_{\mathrm{t}}$ minus $\mathrm{ME}_{\mathrm{t}-1}$ divided by $\mathrm{ME}_{\mathrm{t}-1}$. De dependent variable in models [4]-[6] is the annual market model excess return. Model [1] and [4] include all observations. Model [2] and [5] include the observations for non UK firms only and model [3] and [6] for UK firms only. Models [1]-[6] include observations only if $\mathrm{XCash}_{\mathrm{t}-1}$ is positive. $\Delta \mathrm{L} \mathrm{X}$ indicates a change in $\mathrm{X}$ from time $\mathrm{t}-1$ to $\mathrm{t}$. Governance t.d. is the governance score for Takeover defences. OLS regression is used with White's heteroskedasticity consistent standard errors. Standard erros are presented between parentheses. *,**, and $* * *$ denote statistical significance at the $0.10,0.05$, and 0.01 level, respectively.

\begin{tabular}{|c|c|c|c|c|c|c|}
\hline Variables & [1] & [2] & [3] & [4] & [5] & [6] \\
\hline$\Delta \mathrm{L} \mathrm{XCash} / \mathrm{ME}$ & $\begin{array}{l}1.418^{* *} \\
(0.563)\end{array}$ & $\begin{array}{l}1.183^{*} \\
(0.669)\end{array}$ & $\begin{array}{c}0.377 \\
(2.696)\end{array}$ & $\begin{array}{c}0.998 \\
(0.665)\end{array}$ & $\begin{array}{c}0.931 \\
(0.663)\end{array}$ & $\begin{array}{c}-8.438 \\
(16.061)\end{array}$ \\
\hline$\Delta$ L Earnings / ME & $\begin{array}{c}1.231 * * * \\
(0.256)\end{array}$ & $\begin{array}{c}0.399 \\
(0.484)\end{array}$ & $\begin{array}{c}1.238 \\
(1.458)\end{array}$ & $\begin{array}{c}0.206 \\
(0.422)\end{array}$ & $\begin{array}{c}0.428 * * * \\
(0.111)\end{array}$ & $\begin{array}{c}0.739 \\
(4.002)\end{array}$ \\
\hline$\Delta \mathrm{L}$ Net Assets / ME & $\begin{array}{c}0.110 * * \\
(0.053)\end{array}$ & $\begin{array}{l}-0.136 \\
(0.111)\end{array}$ & $\begin{array}{c}0.359 \\
(0.366)\end{array}$ & $\begin{array}{c}-0.085 \\
(0.122)\end{array}$ & $\begin{array}{c}-0.045 \\
(0.108)\end{array}$ & $\begin{array}{c}4.227 \\
(2.061)\end{array}$ \\
\hline$\Delta \mathrm{L} \mathrm{R} \& \mathrm{D} / \mathrm{ME}$ & $\begin{array}{c}0.053 \\
(1.149)\end{array}$ & $\begin{array}{l}-0.516 \\
(1.380)\end{array}$ & $\begin{array}{c}-11.183 \\
(14.072)\end{array}$ & $\begin{array}{c}2.924 * * * \\
(0.941)\end{array}$ & $\begin{array}{c}1.918 \\
(1.383)\end{array}$ & $\begin{array}{c}-82.567 \\
(146.365)\end{array}$ \\
\hline$\Delta \mathrm{L}$ Interest / ME & $\begin{array}{c}-2.801 * * * \\
(0.796)\end{array}$ & $\begin{array}{l}-1.288 \\
(1.999)\end{array}$ & $\begin{array}{c}16.495 \\
(23.495)\end{array}$ & $\begin{array}{c}-6.112 * * \\
(2.917)\end{array}$ & $\begin{array}{c}-5.952 * * * \\
(1.386)\end{array}$ & $\begin{array}{c}13.518 \\
(24.454)\end{array}$ \\
\hline$\Delta \mathrm{L}$ Dividend / ME & $\begin{array}{l}4.104 * \\
(2.202)\end{array}$ & $\begin{array}{c}1.658 \\
(1.691)\end{array}$ & $\begin{array}{c}5.539 \\
(8.132)\end{array}$ & $\begin{array}{c}-1.968 \\
(2.129)\end{array}$ & $\begin{array}{c}0.739 \\
(1.382)\end{array}$ & $\begin{array}{l}-18.536 \\
(34.370)\end{array}$ \\
\hline Lagged Xcash / ME & $\begin{array}{c}3.052 * * * \\
(0.738)\end{array}$ & $\begin{array}{c}2.329 * * * \\
(0.748)\end{array}$ & $\begin{array}{c}3.093 \\
(1.922)\end{array}$ & $\begin{array}{c}2.313 * * * \\
(0.689)\end{array}$ & $\begin{array}{c}2.268 * * * \\
(0.467)\end{array}$ & $\begin{array}{l}8.062^{* *} \\
(2.041)\end{array}$ \\
\hline Leverage & $\begin{array}{c}-1.297 * * * \\
(0.414)\end{array}$ & $\begin{array}{c}-1.382 * * * \\
(0.325)\end{array}$ & $\begin{array}{l}-1.746 \\
(1.052)\end{array}$ & $\begin{array}{c}-1.279 * * * \\
(0.286)\end{array}$ & $\begin{array}{c}-1.731^{* * *} \\
(0.207)\end{array}$ & $\begin{array}{c}1.846 \\
(3.017)\end{array}$ \\
\hline New Finance / ME & $\begin{array}{c}0.029 * * * \\
(0.008)\end{array}$ & $\begin{array}{c}0.228 \\
(0.362)\end{array}$ & $\begin{array}{c}0.010 \\
(0.017)\end{array}$ & $\begin{array}{c}-0.063 \\
(0.447)\end{array}$ & $\begin{array}{c}0.008 \\
(0.341)\end{array}$ & $\begin{array}{c}-4.318^{* *} \\
(0.954)\end{array}$ \\
\hline Lagged XCash / ME x $\Delta$ L XCash / ME & $\begin{array}{c}2.101 \\
(1.474)\end{array}$ & $\begin{array}{c}5.519 * * * \\
(1.084)\end{array}$ & $\begin{array}{l}-3.631 \\
(7.760)\end{array}$ & $\begin{array}{l}1.041 \\
(0.737)\end{array}$ & $\begin{array}{c}2.180 \\
(1.584)\end{array}$ & $\begin{array}{l}-5.974 \\
(8.949)\end{array}$ \\
\hline Leverage $\mathrm{x} \Delta \mathrm{L}$ XCash / ME & $\begin{array}{c}-0.872 \\
(0.727)\end{array}$ & $\begin{array}{c}-3.938^{* * *} \\
(0.443)\end{array}$ & $\begin{array}{l}-1.532 \\
(5.575)\end{array}$ & $\begin{array}{l}-0.051 \\
(0.920)\end{array}$ & $\begin{array}{c}-1.215^{* *} \\
(0.568)\end{array}$ & $\begin{array}{l}-15.227 \\
(30.944)\end{array}$ \\
\hline Governance t.d. x $\Delta$ L XCash / ME & $\begin{array}{c}0.086 * * * \\
(0.031)\end{array}$ & $\begin{array}{c}0.197 * * * \\
(0.067)\end{array}$ & $\begin{array}{c}0.559 \\
(0.320)\end{array}$ & $\begin{array}{c}-0.012 \\
(0.030)\end{array}$ & $\begin{array}{c}0.110 * * * \\
(0.028)\end{array}$ & $\begin{array}{c}2.932 \\
(3.359)\end{array}$ \\
\hline Governance t.d. & $\begin{array}{c}0.035 \\
(0.022)\end{array}$ & $\begin{array}{c}0.014 \\
(0.038)\end{array}$ & $\begin{array}{c}0.009 \\
(0.119)\end{array}$ & $\begin{array}{l}-0.007 \\
(0.031)\end{array}$ & $\begin{array}{c}0.038 \\
(0.037)\end{array}$ & $\begin{array}{l}-0.212 \\
(0.181)\end{array}$ \\
\hline Constant & $\begin{array}{c}-0.037 \\
(0.118)\end{array}$ & $\begin{array}{c}0.175 \\
(0.231)\end{array}$ & $\begin{array}{c}0.299 \\
(0.619)\end{array}$ & $\begin{array}{c}0.165 \\
(0.172)\end{array}$ & $\begin{array}{c}0.178 \\
(0.138)\end{array}$ & $\begin{array}{c}0.327 \\
(1.443)\end{array}$ \\
\hline Adjusted partial $R^{2}$ & 0.542 & 0.579 & 0.735 & 0.374 & 0.449 & 0.645 \\
\hline Sample Size & 192 & 147 & 45 & 188 & 147 & 41 \\
\hline
\end{tabular}


Table 10. Spending excess cash and corporate governance

This table shows the regression results of the change in Excess Cash on the Governance scores. Assets are net of Cash. The dependent variable in model [1] is the ratio $\left(\right.$ ExcessCash $_{i, t^{-}}$ExcessCash $\left._{\mathrm{i}, \mathrm{t}-1}\right)$ / Assets $_{i, t-1}$ and in model [2] $\left(\right.$ ExcessCash $_{\mathrm{i}, \mathrm{t}^{-}}$ExcessCash $\left._{\mathrm{i}, \mathrm{t}-1}\right) / \mathrm{ME}_{\mathrm{i}, \mathrm{t}-1}$ where $\mathrm{ME}_{\mathrm{i}, \mathrm{t}-1}=$ Market value of Equity at time $\mathrm{t}-1$. The independent variables include the Governance scores Shareholder rights, Takeover defences, Disclosure and Board. The sample is the intersection of firms with positive lagged excess cash and firms for which excess cash declined over the year; i.e. for model $\left(\right.$ ExcessCash $_{\mathrm{i}, \mathrm{t}^{-}}$ ExcessCash $\left._{\mathrm{i}, \mathrm{t}-1}\right) /$ Assets $_{\mathrm{i}, \mathrm{t}-1}<0$ and for model [2] $\left(\right.$ ExcessCash $_{\mathrm{i}, \mathrm{t}^{-}}$ExcessCash $\left._{\mathrm{i}, \mathrm{t}-1}\right) / \mathrm{ME}_{\mathrm{i}, \mathrm{t}-1}<0$. Regressions are made with firm fixed and year fixed effects. OLS regression is used with White's heteroskedasticity consistent standard errors. Standard errors are presented between parentheses. *, **, and $* * *$ denote statistical significance at the $0.10,0.05$, and 0.01 level, respectively.

\begin{tabular}{lccc}
\hline & $\begin{array}{c}\text { Predicted } \\
\text { sign }\end{array}$ & {$[1]$} & {$[2]$} \\
Variables & & & \\
Corporate governance & & 0.005 & 0.001 \\
Shareholder rights & + & $(0.016)$ & $(0.025)$ \\
& & $0.016^{* *}$ & $0.022^{* *}$ \\
Takeover defences & + & $(0.007)$ & $(0.009)$ \\
& & -0.010 & -0.025 \\
Disclosure & + & $(0.013)$ & $(0.024)$ \\
& & -0.010 & 0.003 \\
Board & + & $(0.010)$ & $(0.033)$ \\
& & -0.062 & -0.039 \\
Constant & & $(0.099)$ & $(0.155)$ \\
& & 0.578 & 0.443 \\
Adjusted partial $R^{2}$ & & 119 & 119 \\
Sample Size & & &
\end{tabular}


Table 11. The impact of the use of excess cash and corporate governance on the ROA

This table shows the regression results for the return on assets regressions. The dependent variable is ROA (EBIT over Assets) minus industry average ROA. Assets are computed net of cash. In model [2][5] X ( $\mathrm{X}$ in governance $\mathrm{X}$ ) is equal to, Shareholder rights, Takeover defences, Disclosure and Board respectively. In model [1] $\mathrm{X}$ is equal to the sum of Shareholder rights, Takeover defences, Disclosure and Board. Independent variables are: one-year lagged excess cash to assets, one-year lagged governance scores $\mathrm{X}$, the interaction between lagged excess cash and lagged governance, Size (LN RealAssets), property, plant and equipment to assets (PPE/Assets), and lagged industry adjusted ROA. The sample is the intersection of firms with positive lagged excess cash and firms for which excess cash declined over the year; i.e. $\left(\right.$ ExcessCash $_{\mathrm{i}, \mathrm{t}^{-}}$ExcessCash $\left._{\mathrm{i}, \mathrm{t}-1}\right) /$ Assets $_{\mathrm{i}, \mathrm{t}-1}<0$. Regressions are made with firm fixed and year fixed effects. OLS regression is used with White's heteroskedasticity consistent standard errors. Standard errors are presented between parentheses. *, **, and *** denote statistical significance at the $0.10,0.05$, and 0.01 level, respectively.

\begin{tabular}{lccccc}
\hline Variables & {$[1]$} & {$[2]$} & {$[3]$} & {$[4]$} & {$[5]$} \\
\hline Lagged Xcash & -0.247 & -0.198 & 0.058 & $-0.976^{* * *}$ & -0.478 \\
& $(0.310)$ & $(0.291)$ & $(0.179)$ & $(0.236)$ & $(0.285)$ \\
Lagged Governance X & -0.001 & -0.014 & $-0.004^{* *}$ & -0.008 & -0.002 \\
& $(0.002)$ & $(0.012)$ & $(0.002)$ & $(0.008)$ & $(0.008)$ \\
Lagged Xcash x Lagged Governance X & $0.018^{*}$ & $0.057^{*}$ & 0.018 & $0.172^{* * *}$ & $0.108^{* * *}$ \\
& $(0.009)$ & $(0.031)$ & $(0.013)$ & $(0.029)$ & $(0.032)$ \\
Size & $-0.112^{* * *}$ & $-0.132^{* * *}$ & $-0.137^{* * *}$ & $-0.091^{* * *}$ & $-0.103^{* * *}$ \\
& $(0.037)$ & $(0.037)$ & $(0.034)$ & $(0.032)$ & $(0.036)$ \\
PPE / Assets & $-0.807^{*}$ & $-0.856^{*}$ & $-0.900^{*}$ & $-0.660^{*}$ & $-0.787^{*}$ \\
& $(0.425)$ & $(0.457)$ & $(0.457)$ & $(0.379)$ & $(0.408)$ \\
Lagged ROA & 0.104 & 0.123 & 0.111 & 0.055 & 0.114 \\
& $(0.117)$ & $(0.102)$ & $(0.116)$ & $(0.111)$ & $(0.119)$ \\
Contant & $1.278^{* * *}$ & $1.548^{* * *}$ & $1.541 * * *$ & $1.079^{* * *}$ & $1.190^{* * *}$ \\
& $(0.326)$ & $(0.369)$ & $(0.252)$ & $(0.308)$ & $(0.308)$ \\
Adjusted partial $R^{2}$ & 0.363 & 0.237 & 0.207 & 0.477 & 0.417 \\
Sample Size & 143 & 143 & 143 & 143 & 143 \\
\hline
\end{tabular}




\section{Publications in the Report Series Research ${ }^{*}$ in Management}

\section{ERIM Research Program: "Finance and Accounting"}

2008

The Inefficient Use of Macroeconomic Information in Analysts' Earnings Forecasts in Emerging Markets Gerben de Zwart and Dick van Dijk ERS-2008-007-F\&A

http://hdl.handle.net/1765/11556

Sole versus Shared Responsibility: Fraud Consultation and Auditor Judgment Anna Gold-Nöteberg, W. Robert Knechel and Philip Wallage ERS-2008-010-F\&A

http://hdl.handle.net/1765/11687

Corporate Governance and the Value of Excess Cash Holdings of Large European Firms Marc B.J. Schauten, Dick van Dijk and Jan-Paul van der Waal

ERS-2008-027-F\&A

http://hdl.handle.net/1765/12465

A Conceptual Model of Investor Behavior Milan Lovric, Uzay Kaymak and Jaap Spronk ERS-2008-030-F\&A

http://hdl.handle.net/1765/12468

A complete overview of the ERIM Report Series Research in Management: https://ep.eur.nl/handle/1765/1

ERIM Research Programs:

LIS Business Processes, Logistics and Information Systems

ORG Organizing for Performance

MKT Marketing

F\&A Finance and Accounting

STR Strategy and Entrepreneurship 